\title{
Arap ve Türk Atasözlerinde Ortak Çă̆rışımlar
}

\author{
Fadime Kavak \\ Doç. Dr., Bursa Uludağ Üniversitesi, İlahiyat Fakültesi, Arap Dili ve Belagati Ana Bilim Dalı \\ Bursa/Türkiye \\ fadimekavak@hotmail.com \\ orcid.org/0000-0002-8817-4771
}

Öz: Yaşanan acı tatlı olaylar, mutluluklar, felaketler, tarihi hadiselerden edinilen deneyim ve tecrübeler neticesinde ortaya çıan, her milletin kültür ve medeniyetini, hayat tarzını, yaşam şeklini yansıtan ve söyleyeni belli olmayan meseller (atasözleri); soyut düşünceleri somut şekle büründüren, bir olayı tek cümleyle ifade eden hikmetli sözlerdir. Az sözle çok şey anlatan, verilmek istenen manayı en iyi şekilde ifade eden, teşbih ve kinaye gibi edebi sanatların çokça yer aldığı bu sözler aynı zamanda edebiyatın en güçlü kaynaklarındandır. Milletler arası kültür alışverişi mesellere de yansımış, gerek dini, sosyal ve ticari ilişkiler, gerekse Arapça kaynakların Türkçeye tercüme edilmesiyle Türkler Arap edebiyatındaki meseller ile tanışmıştır. Köklü ve zengin tarihi bir geçmişe sahip olan, Türk edebiyatını da etkilediği görülen bu mesellerle Türk atasözleri kıyaslandığında aralarında benzerlikler olduğu dikkat çekmektedir. Bu benzerlik bazen hem lafız hem mana, bazen de sadece mana yönündendir. Mana yönünden uyumlu olan mesellerin bazıları, kısmî kelime benzerliğinden dolayı bazen lafızdan, bir bölümü de ancak ortaya çıkış hikâyesi öğrenildiğinde anlaşılabilmektedir. Bu yüzden araştırmadaki bazı meseller, daha iyi anlaşılması için hikâyeleriyle birlikte ele alınacaktır.

Anahtar Kelimeler: Arap Edebiyatı, Türk Edebiyatı, Nesir, Mesel (Atasözü), Benzerlik.

Geliş Tarihi/Received Date: 30.01.2021

Kabul Tarihi/Accepted Date: 03.06.2021

Araştırma Makalesi/Research Article

Atıf/Citation: Kavak, Fadime. “Arap ve Türk Atasözlerinde Ortak Çağrışımlar”. Uludağ Üniversitesi İlahiyat Fakültesi Dergisi 30/1 (Haziran 2021), 135-183. https://doi.org/10.51447/uluifd.871493 


\title{
Common Connotations in Arabic and Turkish Proverbs
}

\begin{abstract}
The proverbs that emerge from the experiences of bittersweet events, happiness and disasters, reflect the culture and civilization and life style of every nation and whose people are not known; are wise words that transform abstract thoughts into concrete form and express an event in a single sentence. These words, which tell a lot with little words, express the meaning to be given in the best way, and which include a lot of literary arts such as simile and metonymy, are also one of the most powerful sources of literature. The international cultural exchange was reflected in proverbs, and as a result of both religious, social and commercial relations and the translation of Arabic sources into Turkish, Turks met with proverbs in Arabic literature. When Arabic proverbs, which have a deep-rooted and rich historical background and have been seen to affect Turkish literature, and Turkish proverbs are compared, it is noteworthy that there are similarities between them. This similarity is sometimes in terms of both word and meaning, and sometimes only in terms of meaning. Proverbs, which are compatible in terms of meaning, can be understood sometimes from word and sometimes only when the story of their origin is learned. Therefore, some of the proverbs in the research will be discussed together with their stories for better understanding.
\end{abstract}

Keywords: Arabic Literature, Turkish Literature, Prose, Proverb, Likeness.

[You may find an extended abstract of this article after the bibliography.]

\section{Giriş}

Arapçada “benzemek” anlamındaki “müŝûl” مُشُول kelimesinden türetilen ve çoğulu

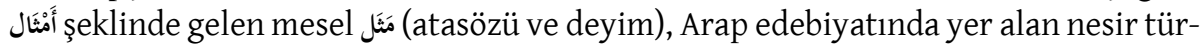
lerinden biridir ve edebi bir değere sahiptir. Arap dili âlimlerinden el-Müberred (ö. 286/900) meseli, مِنَّíden türetilen ve ikincinin durumunun birinciye benzetildiği söz diye tarif ederken; İbnü’s-S1kkît (ö. 244/858) de "Darb1 mesel olan duruma mana yönünden benzeyip lafız yönünden benzemeyen söz" diye tanımlamıştır. ${ }^{1}$

Yaşanan acı tatlı olaylar, mutluluklar, felaketler, tarihi hadiselerden edinilen deneyim ve tecrübeler neticesinde ortaya çıkan, her milletin kendine has duygularını, zevkini, edebiyatını teşkil eden bu sözler; içinde bulunduğu toplumun kültür ve medeniyet seviyesini, hayat tarzını, yaşam şeklini, sosyal ve ruhî yapısını yansıtan ayna gibidirler. ${ }^{2}$ Ayrıca hem içerdikleri bilgi ve düşüncelerin doğruluğu hem de kısa, duru ve özlü cümleler olmaları nedeniyle kolayca hafızalarda kalabilmekte, zengin anlam

1 Muhammed b. Mükerrem İbn Manẓûr, Lisânül'-'Arab (Beyrût: Dâr-u Ṣâdır, ts.), 11/610; Ebu'l-Faḍl Ahmed b. Muhammed el-Meydânî, Mecmécu'l-emșâl, thk. Muhammed Muhyiddîn 'Abdülḥamîd (Beyrût: Dâru'l-Ma'rife, ts.), 1/1; 'Abdülmecîd 'Âbidîn, el-Emșâl fi'n-neșri'l- 'arabiyyi'l-kadîm (İskenderiye: Dâru'l-Ma'rife el-Câmi'iyye. ts.), 6; 'Abdülmecîd Kutâmış, el-Emŝâlül'-'arabiyye (Sûriye: Dâru'lFikr, 1988), 11.

2 Kenan Demirayak, Arap İslam Edebiyatı Literatür Bilgisi (İstanbul, Cantaş Yayınları, 2016), 198-199; Dehri Dilçin, Edebiyatımızda Atasözleri (Ankara: Türk Dil Kurumu Yayınları, 2000), 15. 
içeriği sayesinde de anadilin öğrenilmesine katkı sağlamaktadırlar. ${ }^{3}$ İbrâhîm enNaẓââm (ö. 231/845) mesellerin bu vasfinı şöyle ifade etmiştir: "Şu dört özellik, başka

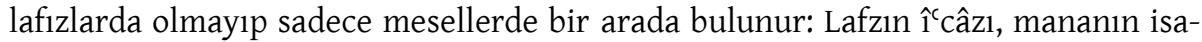
beti, teşbihin güzelliği ve kinayenin mükemmelliği. Bu da belagatin son noktasıdır."

Arap edebiyatında meseller mûcez, kıyâsî ve hurâfî olmak üzere üçe ayrılır. Mûcez meseller yaygın ve veciz olanlardır. Hikmetli veciz sözler, şiir beyitleri ve teşbihte mübalağa ifade eden (أَفْعَُ مِنْ) kalıbındaki meseller bu gruba girer. Kıyâsî olanlar; karşılaştırmaya dayalı teşbih veya temsil yoluyla bir düşünceyi açıklamayı ya da ona delil getirmeyi amaçlayan tasvîrî ve hikayevî anlatımın olduğu mesellerdir. Bunlar tedvin edilen eski Arap meselleri arasında neredeyse hiç yoktur. Bu tür meselleri daha çok Kur'ân'da ve hadislerde görmek mümkündür. Daha sonra İslam bilginleri tarafından Kur'ân ve hadislerdeki mesellerin tarzında kıyâsî meseller oluşturulmuştur. Hurâfî meseller ise hayvanların dilinden aktarılan diğer mûcez sözleri teşkil eder. Bunların gerçeklik ve akli tarafı yoktur. Amaç teselli etmek, eğlendirmek ve ahlaki özelliklere teşviktir. ${ }^{5}$ Bu mesellerin üslubunda daha ziyade teşbih, istiare, kinaye, cinas ve tıbak gibi edebi sanatlar dikkati çeker. Kalıplaşmış ve klişeleşmiş olmaları da filolojik özelliklerinin başında gelir.

Meseller zaman itibariyle Cahiliye ve İslami döneme ait olanlar şeklinde ikiye ayrılabilir. Cahiliye dönemi meselleri o dönemde yaşayan kişilere nispet edilmesi, cahiliye adet ve inançlarını ya da savaş, haber ve olaylarını içermesiyle ayırt edilebilir. Mesellerin ayet, hadislere, sahabe veya tâbiin sözlerine isnat edilmesi de İslami döneme ait olduğunu gösterir. ${ }^{6}$

Genellikle sözlü olarak nesilden nesile nakledilen Arap edebiyatındaki pek çok mesel, ilk defa Emeviler döneminde Mưâviye b. Ebû Süfyân (ö. 60/680) döneminden itibaren "Emŝâl" isimli kitaplarda bir araya getirilmeye çalışılmıştır. Bu eserlerden günümüze kadar ulaşan en eski mesel kitabı el-Mufaḍdal ed-Ḍabbî (ö. 170/786) tarafından te'lif edilen "Kitâbü'l-ems âll"dir. Fazla hacimli olmayan ve yaklaşık 160 meseli ortaya çıkış hikâyeleriyle birlikte ele alan eser, daha sonraki çalışmaların temel kaynağını teşkil eder. Basra dil mektebinin önde gelen simalarından el-Asmâî (ö. 216/831)'nin “Kitâbü'l-ems ŝal”i de bu alanda yazılan ilk eserlerden olup, 500'den fazla meseli ele almaktadır. Bu alanda telif edilen daha hacimli eserler de vardır. Bunlardan biri Ebû Hुilâl el-'Askerî̀nin (ö. 400/1009) yaklaşık 3000 meseli içeren "Cemheretü'l-emŝâl”'i, diğeri de Meydânî’nin (ö. 518/1124) yaklaşık 6000 meseli ele alan "Mecma'u'l-emŝâl"idir. Meydânî bu eserinde eyyâmü'l-‘Arabi, hadisleri, dört halife ve

3 Ahmet Vefik Paşa, Atalar Sözü (Müntehabât-ı ḍurûb-ı emşâl), haz. Recep Duymaz (İstanbul: Gökkubbe Yayınlar1, 2007), 7, 19.

4 el-Meydânî, Mecme‘u'l-emsâl, 1/1.

5 Kutamış, el-Emŝâlü'l-‘arabiyye, 28-32.

6 Kutamış, el-Emşâlül-‘'arabiyye, 125-129; İsmail Durmuş, "Mesel”, Türkiye Diyanet Vakfi İslâm Ansiklopedisi (Ankara: Diyanet Vakfi Yayınları, 2004), 29/293-296. 
bazı önemli kimselerin vecizelerini iki bölüm şeklinde ele almıştır. Mesellerin ortaya çıkışını incelerken İslamiyet'ten önceki bazı olayları anlatması ise esere tarihi bir nitelik kazandırmıştır. Günümüze kadar ulaşan mesel kitaplarının belki de sonuncusu olan Zemahşerî̀nin (ö. 538/1144) "el-Müstekșâ fî emsâ̂li'l-‘Arab" adlı eseri de 3461 mesel ihtiva eden kapsamlı eserlerdendir. ${ }^{7}$ Meselleri içeren bu eserlere bakıldığında Arap halkının tabiatı, sosyo-kültürel yapısı ve tarihinin yanı sıra Arap dilinin lügat ve gramer yapısı hakkında da bilgi edinmek mümkündür.

Milletler arası kültür alışverişi mesellere de yansımış, gerek dini, sosyal ve ticari ilişkiler, gerekse Arapça kaynakların Türkçeye tercüme edilmesiyle Türkler de Arapça mesellerle tanışmıştır. Bunun en güzel örneklerinden biri Bahâuddîn b. Muhammed el-İbşîhînnin (ö. 854/1450) "el-Mustațraffî külli fennin mustaz̧raf” adlı eserinin Şeyhzâde Muhammed Es`ad Efendi tarafından Osmanlıcaya tercüme edilen "Mahmûtu'l-eser fî tercemeti'l-mustațrafi'l-musta'șar" isimli eserdir. Bir başka eser de el-Fîrûzâbâdî’nin meşhur Arapça sözlüğü “el-Ḳâmûsü'l-muhît"inin Mütercim Asım Efendi tarafından Türkçe'ye tercüme edilirken Arapça atasözleriyle zenginleştirilen "el-Okyânûsu'l-basît fî tercemeti'l-kâmusi'l-muhîț"tir. ${ }^{8}$

Köklü ve zengin tarihi bir geçmişe sahip olan, Türk edebiyatını da etkilediği görülen Arap edebiyatındaki meseller ile Türk atasözleri kıyaslandığında aralarında benzerlikler olduğu dikkat çekmektedir. Bu benzerlik bazen hem lafiz hem mana, bazen de sadece mana yönündendir. Mana yönünden uyumlu olan meseller, bazen lafızdan bazen de ancak ortaya çıkış hikâyesi öğrenildiğinde anlaşılabilen sözlerdir. Bu yüzden araştırmadaki bazı meseller hikâyeleriyle birlikte ele alınıp değerlendirilecektir.

Makalede özellikle klasik emsâl kitaplarında bulunan ve Türkçedeki atasözleriyle aynı veya ortak lafız ve anlama sahip olan mesellere yer verilecek, bunlar üç ana başlık altında kategorize edilecektir. Bahsi geçen atasözleri şöyledir:

\section{Lafiz ve Mana Yönünden Ortak Olanlar}

Arapça ve Türkçede hem lafız hem mana yönünden ortak olan atasözlerinde lafızların bazen birbiriyle tamamen örtüştügü, bazen de tek bir kelime farklılı̆̆ı ya da mahzuuf bir öğenin bulunmasından kaynaklanan küçük değişikliklerin olduğu görülmektedir. Ancak Türkçedeki atasözlerinin söyleniş biçimine çok yakın olduğu için, küçük lafız farklılıklarının olduğu bazı Arap meselleri de bu başlık altında ele alınacaktır.

7 Demirayak, Arap Íslam Edebiyatı Literatür Bilgisi, 199-209; Hüseyin Elmalı, "Mufaḍdal ed-Ḍabbî”, Türkiye Diyanet Vakfi İslâm Ansiklopedisi (Ankara: Diyanet Vakfı Yayınları, 2004), 30/364; Zülfikar Tüccar, “Meydânî, Aḥmed b. Muhammed”, Türkiye Diyanet Vakfi İslâm Ansiklopedisi (Ankara: Diyanet Vakfi Yayınlar1, 2004), 29/501.

$8 \quad$ Numan Yazıc1, Atasözleri ve Deyimler (İstanbul: Rağbet Yayınları, 2003), 22. 


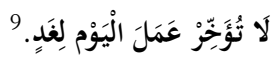

\section{"Bugünün işini yarına bırakma."}

Bir işi zamanında yapmayıp geciktirmek sakıncalıdır. Çünkü yarın başka bir iş çıkabilir ve ertelenen işten önce yapılması gerekebilir. Ya da yapılması gereken işler birikir ve yapması daha da zorlaşabilir. Pek çok iş günü gününe yapılmazsa değerini yitirir ve daha sonra yapılması bir anlam ifade etmez. ${ }^{10}$

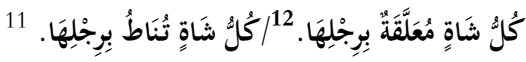

$$
\begin{aligned}
& \text { "Her koyun kendi bacağından asılır." }
\end{aligned}
$$

Herkes yaptığı davranışlardan sorumludur ve cezasını da elbette çekecektir. Şüp-

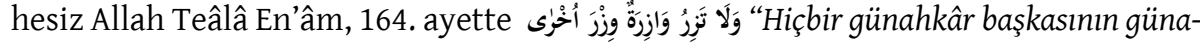
hını yüklenemez" buyurmuştur.

$$
\text { لِكُلِّ دَايِ دَوَاءُ. } 13
$$

\section{"Her derdin bir devast vardır."}

Her türlü sıkıntının, üzüntünün bir çaresi vardır anlamına gelen bir sözdür. ${ }^{14}$

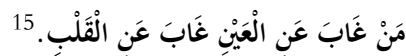

\section{"Gözden trak olan, gönülden trak olur."}

İnsanlar birbirinden uzaklaştıkça aralarındaki sevgi de zamanla azalabilir.

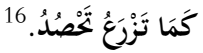

"Ektiğin gibi biçersin" veya "Ne ekersen onu biçersin."

9 İbn 'Abdi Rabbih, el-'Tkdü'l-ferîd (Beyrût: Dârü'l-Kütübi'l-cilmiyye, 1404), 4/301; el-Meydânî, Mecme`u’lemsâll, 2/257.

10 Şükran Eren, Atasözleri ve Deyimler (İstanbul: Meram Yayınları, 1996), 53.

11 Ebû 'Ubeyd el-Ḳâsım b. Sellâm, el-Emŝâl, tah. 'Abdülmecîd Kutâmış (y.y., Dâru'l-Me’mûn, 1980), 274; Ebû Hilâl el-'Askerî, Cemheratü'l-emșâl, thk. Muhammed Ebu'l-Faḍl İbrâhîm, 'Abdülmecîd Kutâmış (y.y., Dâru'l-Fikr, 1988), 2/152.

12 Ebu'l-Ḳâsım Maḥmûd b. 'Umer ez-Zemahsşerî, el-Müstekșâ fî emsâali'l-'Arab, (Beyrût: Dâru'l-Kütübi'l-'ìlmiyye, 1987, 2/227.

13 el-Meydânî, Mecmécu'l-emsâal, 2/257.

14 Atasözlerin açıklamasında genelde Türk Dil Kurumunun sözlüğü kullanılmıştır. Bu yüzden her açıklamanın sonuna dipnot konulmamıştır. bk. Türk Dil Kurumu Sözlükleri (TDK), “Atasözleri ve Deyimler Sözlüğ̈̈” (Erişim 11 Kasım 2020).

15 el-‘Askerî, Cemheratü'l-emsâl, 2/270.

16 el-Meydânî, Mecmécu'l-emsâal, 2/162. 
İnsan nasıl davranırsa öyle muamele görür. İyilik yapan iyilik, kötülük yapan da kötülükle karşılaşır. ${ }^{17}$

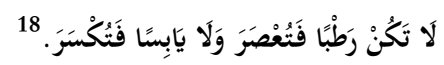

\section{"Yaş olma sıkılırsın, kuru olma kırılırsın."}

Atasözündeki yaş olmakla uysallık ve zayıflık, kurulukla da katılık ve dik başlılık kastedilmektedir. Yani; hayatta ne ezilecek kadar uysal ne de herkesi karşıya alacak kadar sert ve dik başlı olunmalıdır. En iyisi ikisinin ortasını bulmaktır. ${ }^{19}$

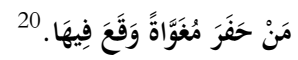

\section{"Başkast için kuyu kazan, (evvelâ) kendi düşer."}

Kötülük, kötülüğü doğurur. Birisine bir tuzak hazırlar, onu zor duruma düşürürsek o kişi, bu tuzağı unutmaz. Fırsatını bulduğunda bizi daha kötü bir tuzağa düşürebilir. Olgun ve erdemli kimse başkalarına kötülük yapmayı düşünmez. Çünkü kuyu kazmak ancak kötü kimselerin işidir. ${ }^{21}$$$
22
$$$$
\text { “Çok konuşan çokyanilır." }
$$

İnsanoğlu ne kadar çok şey bilse de hala öğrenmediği pek çok bilgi vardır. Kendisine aşırı güvenen biri, çoğu şeyi bildiğini düşünerek bilmediği hususlara karışırsa hata eder. ${ }^{23}$

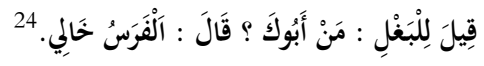

\section{"Katıra 'Baban kim?' demişler, 'Dayım at' demiş."}

Bazı kimseler aşağılık duygusuna kapılarak, kendilerini farklı göstermeye çalışırlar. Bu yüzden iyi yönleriyle övünürken, kötü özelliklerini gizlerler.

17 Eren, Atasözleri ve Deyimler, 161.

18 el-Meydânî, Mecme'u'l-emŝâl, 2/257; Ebû 'Ubeyd el-Bekrî, Faṣlü'l-makâal fî şerhi kitâbi'l-emsâal, thk. İhsân 'Abbâs (Beyrût: Müessetü'r-Risâle, 1971), 317.

19 Ahmet Köklügiller, Açılamalı Atasözleri ve Özdeyişler (İstanbul: Kaya Yayınları, 1994), 58; Eren, Atasözleri ve Deyimler, 172.

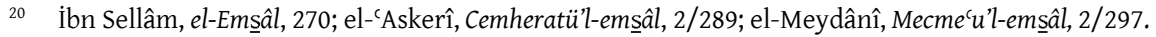

21 Köklügiller, Açıklamalı Atasözleri ve Özdeyişler, 48.

22 el-‘Askerî, Cemheratü'l-emșâl, 1/19; Ebu'ş-Şeyh el-Ișbahânî, Kitâbü'l-emșâl fi'l-hadîsisi'n-nebevî, thk. 'Abdülali ‘Abdülhamîd Ḥâmid (Bombây: ed-Dâru’s-Selefiyye, 1987), 293.

23 Eren, Atasözleri ve Deyimler, 59.

24 el-Meydânî, Mecme`u'l-emsâal, 2/110. 


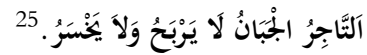 \\ "Korkak bezirgân ne kâr eder ne zarar (ziyan)."}

Tüccar, bir işe girişmekten uzak durur ve korkarsa, zarara uğramaz ancak kazanç da elde edemez. ${ }^{26}$

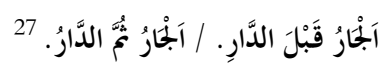

Evden önce komşu (al). / Önce komşu, sonra ev (al).

\section{"Ev alma komşu al."}

Mesel haline gelen ve Peygamber efendimizden rivayet edilen bu söz, komşuluk ilişkileri ve iyi bir komşuya sahip olmanın evden daha önemli olduğunu ifade eder. ${ }^{28}$ Öyleyse bir yere yerleşirken veya ev alırken, kiralarken komşuluk edeceğimiz kişileri iyi tanımamız gerekir. ${ }^{29}$ Komşuluk ilişkileri kötü olursa size evinizi bile sattırır. Arap-

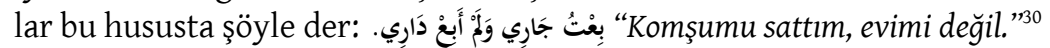

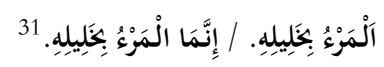

\section{"Kişi, arkadaşıyladır (arkadaşından bellidir)."}

Arkadaşının genel niteliklerine bakarak, tanımak istenilen kişinin nasıl biri olduğu anlaşılabilir.

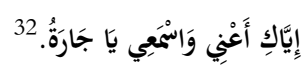

Seni kastediyorum, komşu sen dinle.

\section{"Kızım sana söylüyorum gelinim sen dinle."}

25 el-Meydânî, Mecméu'l-emșâl, 1/154. (Bu manada kullanılan aşağıdaki diğer iki Arap meseli için bk. el'Askerî, Cemheratü'l-emșâl, 1/488; el-Meydânî, Mecme'u'l-emsâal, 1/61)

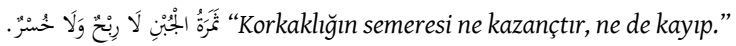

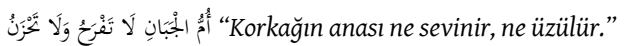

26 Eren, Atasözleri ve Deyimler, 142.

27 ez-Zemahșerî, el-Müstekșâ fî emsâali'l'-'Arab, 1/308.

28 Ebû 'Ali el-Ḥasen b. Mes'ûd b. Muhammed Nûruddîn el-Yûsî, Zehru'l-ekem fi'l-emsâal ve'l-ḥkem, thk. Muhammed Ḥac1, Muhammed el-Aḥ̣ar (el-Mag̉rib: Dâru's-Sekâfe, 1981), 2/58.

29 Köklügiller, Açıllamah Atasözleri ve Özdeyişler, 34.

30 İbn Sellâm, el-Ems̄âl, 278; el-'Askerî, Cemheratü'l-emșâl, 1/203; el-Meydânî, Mecme'u'l-emsâal, 1/104.

31 İbn Sellâm, el-Ems̄âl, 178; el-'Askerî, Cemheratül'-emsâl, 2/251; el-Meydânî, Mecme'u'l-ems̄âl, 2/275.

32 İbn 'Abdi Rabbih, el-`ikdü'l-ferîd, 3/22; Muhammed b. el-Ḥasen b. Muhammed b. 'Ali İbn Ḥamdûn, etTezkkiretü'l-ḥamdûniyye (Beyrût: Dâru Șâdır, 1417), 7/70. 
Kinaye sanatının olduğu bu mesel, herhangi birine doğrudan söylenemeyen düşünce ve uyarıların, dolaylı olarak söylenmesini ifade eder. ${ }^{33}$

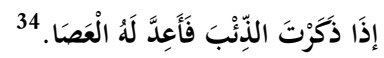

\section{"Kurdu (İti) an, çomağı hazırla."}

Sevilmeyen, tahammül edilmeyen insanların, kendilerinden bahsedilirken geldiklerinde söylenen bir atasözüdür.

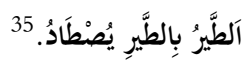

Kuş, kuşla avlanır.

\section{"Kuşu kuşla avlarlar."}

Bir kimseyi elde etmek ve tuzağa düşürmek için daha önceleri ele geçirilen kimse kullanılır. ${ }^{36}$

$$
37 \text { إِنْ كُنْتَ رِيخَا فَفَدْ لَاقَيْتَ إِعْصَارًا. }
$$

Rüzgâr olursan, fırtınayla karşılaşırsın.

\section{"Rüzgâr eken firtına biçer."}

Kötülük yapma eğiliminde olan kimseleri uyarmak, yaptığı kötülüğün daha fazlasıyla karşılaşabileceğini anlatmak için söylenen bir sözdür. Çünkü kötülükten zarar görenler daha sert ve ağır bir şekilde karşılık verebilirler. ${ }^{38}$

$$
\text { اَحَرْكَةُ بَرَكَةُ. } 39
$$

Hareket berekettir.

\section{"Nerede hareket, orada bereket."}

Sürekli çalışılan, hareket halinde olunan yerde bereket ve bolluk olur. ${ }^{40}$

$$
\text { ألْوَلَدُ كَمَدُ. }
$$

33 İbrâhîm Muștafa vd., el-Mu'cemu'l-vesiț, thk. Mecme' 'u'l-lugati'l-'arabiyye (y.y., Dâru'd-Da've, ts.), $1 / 146$.

34 el-Meydânî, Mecme'u'l-emșâl, 1/87.

35 el-Meydânî, Mecmécu'l-emșâl, 1/442.

36 Eren, Atasözleri ve Deyimler, 149.

37 el-Meydânî, Mecme'u'l-emșâl, 1/333; ez-Zemahşserî, el-Müstekșâ fì emșâli'l'-Arab, 1/373; el-Yûsî, Zehru'lekem fi'l-emsâl, 1/99.

38 Köklügiller, Açklamalı Atasözleri ve Özdeyişler, 60.

39 el-Meydânî, Mecme'u'l-emsâl, 1/230.

40 Eren, Atasözleri ve Deyimler, 162.

${ }^{41}$ el-Yûsî, Zehru'l-ekem fi'l-emsấl ve'l-ḥıkem, 1/301. 
Çocuk derttir, sıkıntıdır.

"Evladın mi var, derdin var."

Çocukların sıkıntıları, üzüntüleri, hastalıkları anne babası için daima derttir.

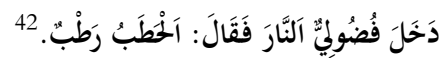

Boşboğaz ateşe girmiş, odun yaş demiş.

\section{"Boşboğazı ateşe atmışlar, odun yaş demiş."}

Çok konuşan ve çenesi düşük diye tabir edilen kimseler, umulmadık zamanlarda densiz bir şekilde konuşabilir.

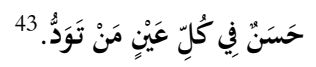

Her göze, sevdiği güzel görünür.

\section{"Gönül kimi severse güzel odur."}

Güzellik görecelidir ve herkesin kendine ait zevkleri vardır. Birine göre güzel olan şey, başkasına göre olmayabilir. ${ }^{44}$

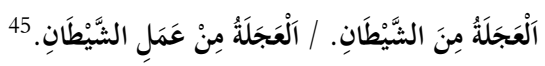

Acele etmek şeytandandır. / Acele etmek şeytanın işidir.

\section{"Acele işe şeytan karışır."}

Yeterince düşünüp kafa yormadan, alelacele yapilan işten iyi ve istenilen sonuç elde edilemez.

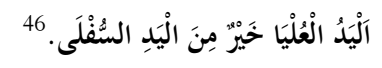

\section{"Veren el, alan elden üstündür."}

Peygamber efendimizden rivayet edilen bu hadiste sadaka vermeye teşvik vardır.

$$
\text { إعْقِلْ وَتَوَكَّْْ. } 47
$$

(Deveyi) bağla ve Allah'a tevekkül et.

\footnotetext{
42 el-Meydânî, Mecméu'l-emsâ̂l, 1/274.

43 el-'Askerî, Cemheratü'l-emsâal, 1/357; el-Meydânî, Mecme'u'l-emșâl, 1/196; ez-Zemahşererî, el-Müstekșâ fî emsâali'l-'Arab, 2/63; el-Yûsî, Zehru'l-ekem fi'l-emŝâl, 2/262.

44 Köklügiller, Açıklamalı Atasözleri ve Özdeyişler, 161.

45 el-‘Askerî, Cemheratü'l-emșâl, 1/26; el-Yûsî, Zehru'l-ekem fi'l-emśâl ve'l-hı̣kem, 2/189.

46 el-Meydânî, Mecme`u'l-emșâl, 2/414; ez-Zemahșerî, el-Müstekșâ fî emșâli'l-'Arab, 1/356.

47 el-Meydânî, Mecmécu'l-emsâ̂l, 2/26.
} 


\section{"Eşeği sağlam kazığa bağla, sonra Allah'a tevekkül et." 48}

Bir işin sonuçlanmasına engel olacak şeyleri ortadan kaldırıp, gerçekleşmesini sağlayacak şartları oluşturmak gerekir.

\section{اَحَحُبُْ أَعْمَى. \\ “Aşk(ın gözü) kördür." (Aşı̆ğı gözü kördür)}

Âşık olan kimse, aşkından dolayı sevdiğinin kusurlarını göremez ve çevresindeki olaylarla da pek ilgilenmez. Bu manaya gelen diğer meseller de şunlardır:

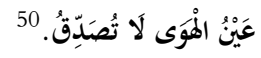

Aşkın gözü inanmaz (kördür).

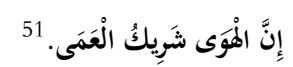

Aşk körlüğün ortağıdır.

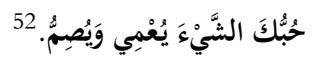

Bir şeyi sevmen kör ve sağır eder.

\section{Sadece Mana Yönünden Ortak Olanlar}

Klasik emsâl kitapları incelendiğinde doğruluk, dürüstlük, iyilik, kötülük, dostluk, arkadaşlık, akrabalık, komşuluk, birlik-beraberlik, güzellik, acelecilik, sabırlı olmak, firsatları değerlendirme, tutumlu olma, kader, kısmet vb. pek çok konuyla ilgili mesellere rastlamak mümkündür. Türk atasözleriyle lafiz yönünden değil de sadece mana yönünden benzer olan Arap mesellerine baktığımızda da bahsi geçen konularda pek çok mesel dikkat çekmektedir. Bu yüzden bu başlık altında ele alacağımız meselleri konularına göre tasnif etmek yararlı olacaktır.

\section{1. İyilik ve Kötülük}

İnsanın sahip olabileceği en önemli değerlerden biri sayılan, toplumun da huzur ve refahını sağlayan iyilik gerek ayet ve hadislerde gerekse atasözlerinde sıkça değinilen temalardan biridir. İyilik yapan kimsenin iyilik, kötülük yapanın da kötülük bulacağı söylenilen atasözlerinde iyiliğe teşvik ve kötülükten alıkoyma söz konusudur. Ancak insan yaptığı iyiliğin karşılığında her zaman iyilikle karşılaşmayabilir. Çünkü

48 Vefik, Atalar Sözü, 140.

49 ez-Zemahşserî, el-Müstekșâ fî emsấli'l-‘Arab, 1/309.

50 el-Meydânî, Mecme'u'l-emsâal, 2/55.

51 el-Meydânî, Mecme‘u'l-emsâal, 1/78.

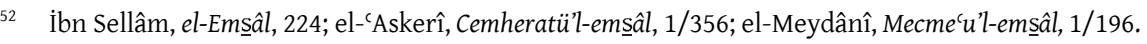


bazı insanlar kendisine yapılan iyiliğin değerini anlamazlar. Bu yüzden bazı mesellerde bu kimseler yerilmekte, ama yine de iyilik yapmaktan vazgeçilmemesi gerektiği, Allah Teâlâ'nın bunu karşılıksız bırakmayacağı ifade edilmektedir.

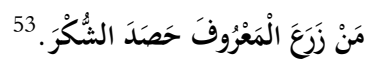

Kim iyilik ekerse teşekkür elde eder.

\section{"Iyilik eden iyilik bulur."}

İyilik yapan kişiye, vakti zamanı gelince başkaları da iyilik edecektir.

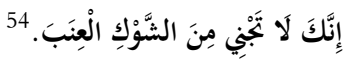

Dikenden üzüm devşiremezsin.

\section{"Arpa eken, buğday biçmez."}

Ne ekerseniz onu biçersiniz. Bu yüzden kötü davranışın karşllı̆̆ında iyilik bekleyemezsiniz.

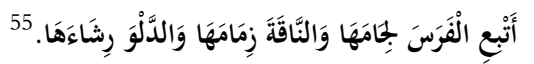

Atı dizgini, deveyi yuları, kovayı da ipiyle birlikte bağışla.

\section{"Ettin bir hayır, tut bacağın ayır." ${ }^{6}$}

Ettiğin hayrı tam yap anlamına gelen bir atasözüdür.

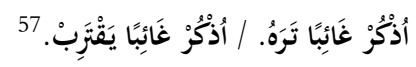

Yanında olmayanı an ki onu göresin. / Yanında olmayandan bahset ki gelsin.

\section{"İyi insan lafinı üzerine gelir."}

Kendisinden bahsedilen kimse, konuşma anındaki ortama gelirse iyi bir kişi olarak değerlendirilir.

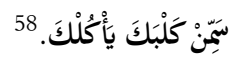

Besle köpeğini seni yesin (1sırsın).

\section{"Besle kargayl oysun gözünü."}

\footnotetext{
53 el-Meydânî, Mecméu'l-emșâl, 2/327.

54 İbn Sellâm, el-Emșâl, 264; el-‘Askerî, Cemheratü'l-emșâl, 1/105; el-Meydânî, Mecme'u'l-emșâl, 1/52.

55 el-Meydânî, Mecme'u'l-emsâl, 1/134; el-Yûsî, Zehru'l-ekem fi'l-emșâl, 1/309.

56 Vefik, Atalar Sözü, 141.

57 el-Meydânî, Mecmécu'l-emșâl, 1/280.

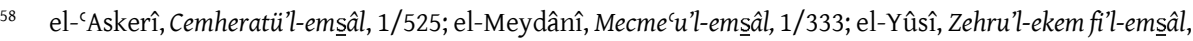
$3 / 180$.
} 
Yapılan iyiliğin değerini bilmeyen bazı kimseler, kendilerine yararı dokunan kimselere zarar verebilirler. ${ }^{59}$

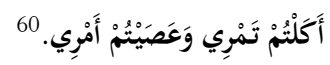

Hurmamı yediniz sonra da emrime karşı geldiniz.

\section{"Köpek bile yal yediği kaba pislemez."}

Köpek bile yemeğini yediği kabı pisletmezken, insanın geçimini karşılayan kişiye veya yere kötülük etmesi düşünülemez.

$$
\text { التَّقِ شَرَّ مَنْ أَحْسَنْتَ إِلَيْهِ. }
$$

İyilik yaptığın kimsenin kötülüğünden sakın.

\section{"İyiliğe iyilik olsaydı, koca öküze bıçak olmazdı."}

Öküz, hayatı boyunca sahibine hizmet edip fayda sağlamasına rağmen ihtiyarladığında onun tarafından kesiliyorsa, bu dünya hayatında da insan, her zaman yaptığı iyiliğin karşılığını göremez. Bu anlamda kullanılan bir başka atasözü de şudur: "İyilik et denize at, balık bilmezse Hâlık bilir"

$$
\text { لَا يَضُرُ السَّحَابِ نُبَاحُ الْكِلاًبِ. }
$$

Köpeklerin havlaması buluta zarar vermez.

\section{"İt ürür, kervan yürür."}

Doğru yolda olanlara engel olmaya çalışanlar, bir yerden geçen kervana ürüyen itlere benzetilmiştir. İtlerin ürümesi, kervanın gidişine engel olamadığı gibi, kıskanç kimselerin sataşmaları ve alıkoyma çabaları da hak bildikleri yolda gidenleri engelleyemez. ${ }^{63}$

\subsection{Dostluk ve Arkadaşlik}

Gerek Arap gerekse Türk edebiyatında dostluk ve arkadaşlıkla ilgili pek çok mesel (atasözü) bulunmaktadır. Bunlar anlam yönünden de birbirine oldukça benzemektedir. Bu mesellerde dostun nasıl olması gerektiği, hangi şartlarda daha iyi tanındığı, dostlarla gereğinden fazla yakınlık kurmanın faydasından çok zararı olduğu; iyi kimselerin iyi, kötülerin de kötü kişilerle arkadaşlık yaptığı, kişilerin arkadaşlarından hem olumlu hem de olumsuz yönde etkilendiği, arkadaş seçiminin ve akılll dostlar edinmenin ne kadar önemli olduğu üzerinde durulmaktadır.

\footnotetext{
59 Köklügiller, Açıklamalı Atasözleri ve Özdeyişler, 115; Eren, Atasözleri ve Deyimler, 44.

60 el-Meydânî, Mecmé 'u'l-emșâl, 1/111, 408; ez-Zemahşşerî, el-Müstekșấfi emșâli'l-‘Arab, 1/296.

61 el-Meydânî, Mecmécu'l-emsâal, 1/145.

62 el-Meydânî, Mecme`u'l-emșâl, 2/215, 408; ez-Zemahşserî, el-Müstekșâ fî emșâli'l-‘Arab, 2/272.

63 Köklügiller, Açıklamalı Atasözleri ve Özdeyişler, 179; Eren, Atasözleri ve Deyimler, 121.
} 


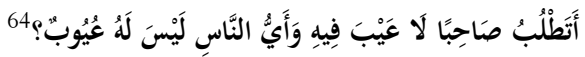

Kusursuz dost mu istiyorsun? Hangi insanın kusuru yok ki?

"Kusursuz dost arayan dostsuz kalır."

Kusursuz dost arayan kimse, dostsuz kalır. Çünkü herkesin bir kusuru vardır. ${ }^{65}$

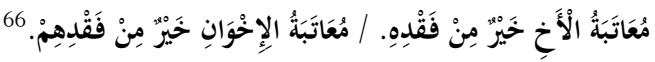

Dostların (senin) ayıbını yüzüne vurması, onları kaybetmenden daha iyidir.

\section{"Dost dostun ayıbını yüzüne söyler."}

Hakiki dost, hatamızı yüzümüze söyler ve arkadan konuşmaz. Böylece biz de hatalı davranışımızı düzeltir, bir daha aynı duruma düşmemeye çalışırız. ${ }^{67}$

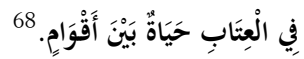

Dostun tanıdıkları kınamasında hayat vardır.

\section{"Dost act söyler"; "Dostun attığı taş baş yarmaz."}

Çevremizdeki bazı insanlar biz üzülmeyelim diye hatalarımızı söylemekten çekinirler. Ama yakın dost ve arkadaşlarımız hoşumuza gitmeyecek olsa bile yanlışlarımızı açık açık söylemekten çekinmezler. Çünkü gerçek dostluk bunu gerektirir. ${ }^{69}$

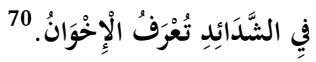

Dostlar, sıkıntılı anlarda tanınır.

\section{"Dost kara günde belli olur."; "Altın ateşte, insan mihnette belli olur."}

Normal zamanlarda herkes bize dost görünebilir. Altının saf olup olmadığı nasıl ateşte anlaşılıyorsa gerçek dost da üzüntülü ve sıkıntılı günlerde belli olur. ${ }^{71}$<smiles>[Al]=[14C][As]</smiles>

Kişi kardeşinin (dostunun) aynasıdır.

\footnotetext{
64 Aḥmed el-Hâşimî, es-Siḥru'l-ḥalâl ve fi'l-ḥıkem ve'l-emŝâl (Beyrût: Dâru'l-Kütübi'l-'ílmiyye, ts.), 22; elYûsî, Zehru'l-ekem fi'l-emsâll, 1/250.

65 Eren, Atasözleri ve Deyimler, 148.

66 İbn Sellâm, el-Emŝâl, 182; el-Meydânî, Mecme`u'l-emșâl, 2/317.

67 Köklügiller, Açıllamalı Atasözleri ve Özdeyişler, 145.

68 el-Meydânî, Mecme‘u'l-emsâal, 2/317.

69 Köklügiller, Açıklamalı Atasözleri ve Özdeyişler, 145, 146.

70 el-Hâşimî, es-Sihru'l-halâl ve fi'l-ḥıkem ve'l-emsâal, 106.

71 Köklügiller, Açılamalı Atasözleri ve Özdeyişler, 93.

72 el-‘Askerî, Cemheratü'l-ems ŝal, 1/72.
} 


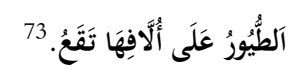

Kuşlar sevdiği kimseleri bulur.

\section{"Bana arkadaşını söyle, sana kim olduğunu söyleyeyim."}

İnsanlar kendilerine yakın buldukları ve benzer tarza sahip kimselerle arkadaşlık kurarlar. Dolayısıyla birisinin arkadaşına bakarak nasıl bir kişiliğe sahip olduğunu anlamak mümkündür. Bu manaya gelen başka bir Türk atasözü de şudur: "Baz bazla, kaz kazla, kel tavuk topal horozla" 74

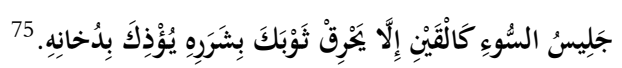

Arkadaşın kötüsü demirci gibidir. Kıvılcımıla kıyafetini yakmasa bile dumanıyla sana zarar verir.

\section{"Üzüm üzüme baka baka kararı"; "Kır atın yanında duran ya huyundan ya suyundan"; "İsin yanina varan is, misin yanina varan mis kokar."}

Kişi çevresinden ve arkadaşlık, yakınlık kurduğu kimselerden olumlu ya da olumsuz yönde etkilenebilir. Bu yüzden arkadaş seçiminde dikkatli olmak gerekmektedir. $^{76}$

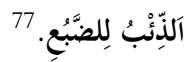

Kurt, sirtlanı (bulur).

\section{"It itle gezer"; "İt ulur, birbirini bulur."}

Kötü kimse ancak kendisi gibi kötü birini bulur. Adi, aşağılık kimse herhangi bir durumda sesini yükseltince amacı aynı olanlar da onun çevresinde toplanır. ${ }^{78}$

$$
\text { اَحَحْاوِي لَا يَنْجُو مِنَ الحَيَّاتِ. }
$$

Y1lan oynatıcısı (hokkabaz) yılanların (sokmasından) kurtulamaz.

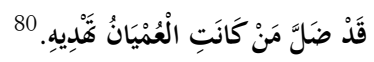

Rehberi kör olan yolunu şaşırır.

73 el-Meydânî, Mecme'u'l-emsâ̂l, 1/442.

74 Köklügiller, Açıklamalı Atasözleri ve Özdeyişler, 202. Bu atasözünün bir başka versiyonu da şöyledir: "Kaz kazla, baz bazla, kel tavuk kel horozla.”; bk. Muẓaffer Luṭfi, Türk Atalar Sözü, (y.y., Matba‘ai Ebüẓ̦iya, 1928), 36.

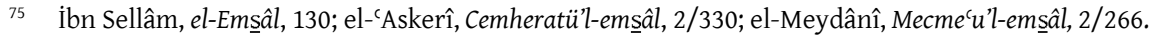

76 Köklügiller, Açıklamalı Atasözleri ve Özdeyişler, 67.

77 el-Meydânî, Mecméu'l-emsâl, 1/282.

78 Eren, Atasözleri ve Deyimler, 121.

79 el-Meydânî, Mecmécu'l-emŝâl, 1/230.

80 el-Meydânî, Mecmécu'l-emsâal, 2/129. 


\section{"Körle yatan şaşı kalkar"; “ittle yatan bitle kalkar."}

Kötü, değersiz kimselerle yakınlık veya arkadaşlık kuranlar, kötü huylar edinirler. ${ }^{81}$

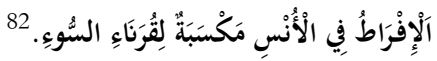

Dostluklarda fazla yakınlık, kötü arkadaşlıklara sebep olur.

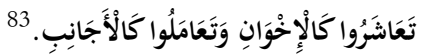

Dost gibi yaşayın, yabancı gibi davranın.

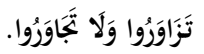

Birbirinizi ziyaret edin ama komşu olmayın (yakınlaşmayın).

\section{"Seyrek git sen (sıkça varma) dostuna, kalksın ayaküstüne"; "Sık gidersen dostuna, yatar} arka üstüne"; "Çok muhabbet tez ayrllk getirir."

Kişi sık sık dostuna giderse, nadiren gittiği zamanlardaki misafirperverliği göremez.

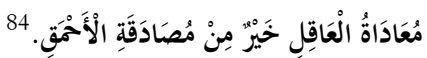

Akıllı kişinin düşmanlığı, ahmak kimsenin dostluğundan daha iyidir.

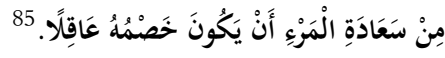

Düşmanının akıllı olması kişiyi mutlu eder.

\section{"Akıllı düşman, akılsız dosttan hayırlıdır"; "Deli dostun olacağına akıllı düşmanın olsun."}

Akılsız olan kimselerle dostluk kurulmaz. Çünkü iyi niyetli olsalar bile, davranışlarının ne gibi olumsuz neticeler doğuracağını hesap edemediklerinden dostlarına farkında olmadan kötülük yapabilirler. Oysa akıllı düşmanın yapacağı kötülügü fark edip önlem almak mümkündür. ${ }^{86}$

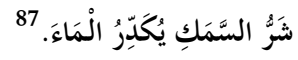

Balığın kötüsü suyu bulandırır.

"Düşmanın karınca ise de hor bakma"; "Düşsmanın karınca olsa kendini merdane tut."

\footnotetext{
$81 \quad$ Eren, Atasözleri ve Deyimler, 145.

82 el-Meydânî, Mecmécu'l-emŝâl, 2/79.

83 el-Meydânî, Mecme'u'l-ems ŝal, 1/150.

84 el-Bekrî, Faṣlü'l-makâl fî şerhi kitâbi'l-emșâl, 187.

85 el-Meydânî, Mecmécu'l-emsâal, 2/327.

86 Eren, Atasözleri ve Deyimler, 23; Köklügiller, Açılamalı Atasözleri ve Özdeyişler, 89.

87 el-Meydânî, Mecméu'l-emsâal, 1/391.
} 
Düşmanın ne kadar zayıf olursa olsun her daim uyanık ve dikkatli ol.

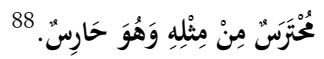

Kendisi temkinli ama başkaları da kendisine karşı ihtiyatlı.

\section{"Tencere dibin kara, seninki benden kara."}

\section{"Tencere tencereye 'yüzün kara' demiş, çömlek utancından yere geçmiş."}

Karşımızdaki kimsede kusur veya hata aramaya çalışmamalıyız. Yoksa o da kendisinden daha beter olduğumuzu ifade etmek için bizim hatalarımızı söylemeye kalkışır.

\subsection{Akrabalik ve Soya Çekim}

Akrabalık, yakınlık göstermeyi ve zor günde yanında olmayı gerektirir. Ancak her akraba aynı yakınlığı, samimiyeti göstermez; hatta bazıları zarar verme eğilimi içindedir. Bu yüzden bu tür akrabalar akrebe benzetilmiştir.

$$
\text { اَلْأَقَارِبُ عَقَّارِبُ. }
$$

Akrabalar akrep (gibidir).

\section{"Akrabanın akrabaya ettiğini akrep etmez."90}

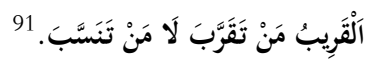

Akraba seninle aynı soydan gelen değil, sana yakınlık gösterendir.

"Yakın (hayırli) dost (komşu), uzak (hayırsız) akrabadan yeğdir (iyidir)."

Yardımlarını esirgemeyen dost ve komşular, hiçbir iyiliği dokunmayan akrabalardan daha yakındır.

$$
\text { إبْنُكَكَ إِبُُْ بُوحِكَ. }
$$

Oğlun, senin sulbundan olandır (evlat edindiğin değil).

“Üvey öz olmaz, kemha bez olmaz"; “Çam ağacından ağıl, el çocuğundan oğul olmaz.”

88 İbn Sellâm, el-Emșâl, 74; el-Meydânî, Mecme'u'l-emșâl, 2/321; ez-Zemahşserî, el-Müstekșâfí emsâali'l-‘Arab, 2/342; el-Yûsî, Zehru'l-ekem fi'l-emŝâl, 2/113.

89 el-Yûsî, Zehru'l-ekem fi'l-emsấl, 1/301.

90 Vefik, Atalar Sözü, 98.

91 el-Yûsî, Zehru'l-ekem fi'l-emsâl, $3 / 37$.

92 el-‘'Askerî, Cemheratü'l-emsâal, 1/39; el-Meydânî, Mecme‘u'l-emsâal, 1/101; el-Yûsî, Zehru'l-ekem fi'l-ems sâl, $1 / 205$. 
Her insanın, her şeyin kendine özgü bir değeri vardır. Bir kişinin yerini bir başkası alamayacağı gibi, bir şeyin yerine de başka şey konulmaz. ${ }^{93}$ Bir çocuk her ne kadar sevilse, ilgi ve alaka görse de kendi annesindeki merhamet ve şefkati üvey annesinde bulamaz. Çünkü öz annenin yerini hiçbir üvey anne tutamaz.

$$
\text { أَبَى مَنْبتُ الْعِيدَانِ أَنْ يَتَغَيَّ. } 94
$$

Kamışların yetiştiği yer değişmez.

\section{"Soy asma soyuna çeker"; "Cins cinse çeker"; "Soydur çeker, b..ktur kokar"; Cins horoz yu-} murtada öter."

Her insan az çok soyuna benzer. Temiz soydan gelen kişi, her haliyle soyluluğunu gösterir.$^{95}$ Çocuğun soyu daha küçükken hal ve davranışlarından anlaşılabilir. ${ }^{96}$

\subsection{Toplumsal İlişkiler}

Toplumsal hayatın belli bir düzen içinde devam edebilmesi için insanların uyması gereken bazı kurallar vardır. Bunlar toplumdan topluma farklılık arz edebileceği gibi, ortak özelliklere de sahiptir. Aşağıdaki benzer anlama sahip atasözlerinde hem Arap hem Türk toplumunda sosyal ilişkilerin nasıl olması gerektiğini açıç̧a görmek mümkündür.

$$
\text { مِنْ كَثْرَة الْمَلَّاحِينَ غَقَقَتِ السَّفِينَةُ. }
$$

Denizciler çok olduğundan dolayı gemi battı.

"íki kaptan bir gemiyi batırı"; "Horozu çok olan köyde sabah geç olur"; "Dokuz at bir kazığa bağlanmaz"; "ïki aslan bir posta siğmaz"; "Nerede çokluk, orada b..kluk."

Bir konu hakkında konuşan çok olursa; kimin ne söylediği, hangisinin doğru olduğu konusunda karar vermek ve bir neticeye ulaşmak zorlaşır. ${ }^{98}$ Ayrıca bir işin başına, alanında uzman birden fazla kişi getirilirse anlaşamazlar ve birbirlerine düşerler.

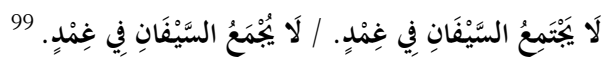

İki kılıç bir kına sı̆̆maz.

\footnotetext{
93 Eren, Atasözleri ve Deyimler, 57.

94 el-Yûsî, Zehru'l-ekem fi'l-emŝâl, 1/144; el-Bekrî, Faṣlü'l-makâal fi şerhi kitâbi'l-em șâl, 221.

95 Eren, Atasözleri ve Deyimler, 34.

96 TDK, “Atasözleri ve Deyimler Sözlüğü".

97 el-Meydânî, Mecméu'l-emsâ̂l, 2/327.

98 Köklügiller, Açılamalı Atasözleri ve Özdeyişler, 170.

99 İbn Sellâm, el-Emșâl, 279; el-Meydânî, Mecméu'l-emşâl, 2/230; el-Bekrî, Faṣlü'l-makâl fi şerhi kitâbi'lemsâl, 394.
} 
"İki aslan bir posta sığmaz"; "İki at bir kazığa bağlanmaz"; "İki baş bir kazanda kaynamaz"; "íki cambaz bir ipte oynamaz."

İki kişinin bir hususta ittifak edemeyeceğini ya da aynı işte birlikte çalışamayacağını ifade eden bir meseldir. ${ }^{100}$

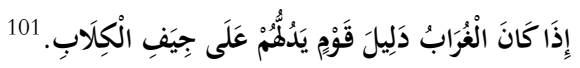

Karga, rehberi olduğu topluluğu köpeklerin leşine götürür.

"Kilavuzu karga olanin burnu b..ktan kalkmaz."

Kötü kimselerle arkadaşlık yapan, onlara uyan kimselerin başları hiçbir zaman dertten kurtulmaz.

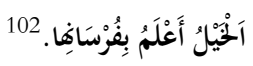

Atlar binicisini iyi bilir.

\section{"At sahibine (binicisine) göre kişner"; "At sahibine göre eşinir."}

İnsanlar, başlarındaki kişinin tesirinde kalarak davranış sergilerler.

$$
\text { كُلُْ كَلْبِ بِبَابِهِ نَبَّاحُ. } 103
$$

Her köpek kendi kapısında havlar.

\section{"Her horoz kendi çöplüğünde öter."}

Herkes içinde bulunduğu çevrede bir değere sahiptir ve sözünü geçirebilir. ${ }^{104}$

$$
\text { مَنْ غَرْبَلَ النَّاسَ نَخَلُوهُ. }
$$

Kim insanları kalburdan geçirirse, insanlar da onu elekten geçirir.

"Alma mazlumun ahını, çıkar aheste aheste"; "Rüzgâr eken firtına biçer."

Yaptığın kötülüklerin sana dönmesini istemiyorsan, kimseye işkence edip de ahını almamalısın.

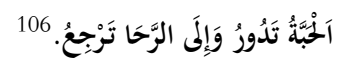

Tane dönüp dolaşıp değirmene gelir.

\footnotetext{
100 Eren, Atasözleri ve Deyimler, 112.

101 el-Hâşimî, es-Siḥru'l-ḥalâl ve fi'l-ḥıkem ve'l-emsâal, 10.

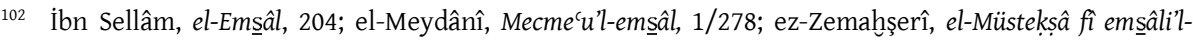
'Arab, $1 / 238$.

103 el-Meydânî, Mecme`u'l-emsâ̂l, 2/135.

104 Eren, Atasözleri ve Deyimler, 105.

105 el-Meydânî, Mecme`u'l-emŝâl, 2/321.

106 el-Meydânî, Mecme`u'l-ems ŝal, 1/230.
} 


\section{"Tilkinin dönüp dolaşıp geleceği yer, kürkçü dükkânıdır."}

İnsanlar her ne kadar farklı işlerle uğraşıp farklı şekilde yaşamaya çalışsalar da daha önceden sahip oldukları çevreye veya işe dönerler.

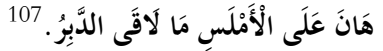

Sırtı yara içinde olan hayvanın çektiği acı, sağlam hayvana önemsiz gelir.

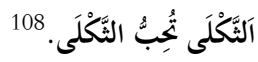

Çocuğunu kaybeden anne, çocuğunu kaybedeni sever.

\section{"Damdan düşen damdan düşenin hâlini bilir."}

Başına kötü bir iş gelen kimsenin durumunu, ancak daha önce o durumu yaşayan anlar. $^{109}$

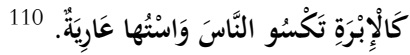

İğne gibi kendi çıplak olduğu halde insanları giydirir.

\section{“Terzi kendi söküğünü dikemez."}

\section{“Kürkçünün kürkü olmaz, börkçünün börkü."}

Bir kimse sahip olduğu kabiliyetini ve bir konudaki uzmanlığını kullanarak başkalarının gereksinimlerine çare bulur ancak kendi ihtiyaçlarını savsaklar.

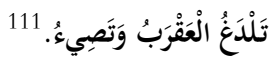

Akrep hem sokuyor hem de ses çıkarıyor.

\section{"Hem suçlu hem güçlü."}

Gerçek suçlu kendisi olmasına rağmen başkalarını suçlayan kimseler için söylenen bir sözdür.

$$
\begin{aligned}
& \text { يَحُجُ وَالنَّاسُ رَاجِعُونَ. } 112 \\
& \text { İnsanlar (hacdan) dönerken, o hac yapar. } \\
& \text { "Herkes gider Mersin'e, biz gideriz tersine." }
\end{aligned}
$$

Sırf muhalefet olsun diye herhangi bir işin aksinin yapılmasını ifade eder.

\footnotetext{
107 el-'Askerî, Cemheratü'l-emsâal, 2/361; el-Meydânî, Mecme‘u'l-emșâl, 1/100.

108 el-Meydânî, Mecme`u'l-emŝâl, 1/153.

109 Eren, Atasözleri ve Deyimler, 63.

110 el-Meydânî, Mecmécu'l-emsâal, 2/171.

111 el-Meydânî, Mecme $e^{`} u^{\prime}$-ems

112 el-Meydânî, Mecme`u'l-emŝâl, 2/427.
} 


\subsection{Doğruluk ve Dürüstlük}

Toplumda insanların iyi geçinebilmesi için birbirlerine karşı doğru sözlü olmaları ve dürüst davranmaları çok önemlidir. Dürüstlüğün olduğu yerde dostluk, arkadaşlık ve akrabalık bağları da daha güçlü olur. Hem Hz. Peygamber hem de ecdat, söylediği sözlerde daima doğru ve dürüst olmak gerektiği hususunda tavsiyelerde bulunmuşlardir.

$$
\text { مَنْ صَدَقَ اللَهَ نَجَا. }
$$

Kim Allah'a karşı samimi olursa kurtulur.

\section{"Doğrunun yardımcısı Allah'tır."}

İşlerinde hakkı gözeten kimseye Allah daima yardım eder. ${ }^{114}$

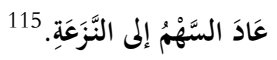

Ok, mahir okçulara geri döndü.

\section{"Hakyerini bulur"; "Hak yerde kalmaz."}

Kişi emeğinin karşılığın daima alacaktır.

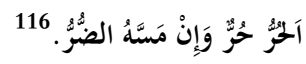

Saygın insan zarar görse de saygındır.

\section{"Altın yere düşmekle pul olmaz"; "Altın çamura düşmekle kıymetten düşmez."}

Değerli kişi veya nesneler, kötü bir durumla karşılaşsalar bile asla değerlerinden bir şey kaybetmezler. ${ }^{117}$

Yukarıdaki mesellerde doğru sözlü ve dürüst olmanın öneminden bahsedilirken aşağıdaki atasözlerinde doğruyu söyleyenlerin sevilmediğinden söz edilmektedir.

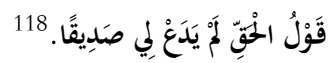

Doğru söylemek bana arkadaş bırakmadı.

"Doğru söyleyeni dokuz köyden kovarlar"; “Doğru söyleyenin bir ayağı üzengide gerek”; "Doğru söyleyenin tepesi delik olur."

\footnotetext{
113 İbn Sellâm, el-Emșâl, 3; el-Meydânî, Mecme`u'l-emșâl, 2/296; el-Bekrî, Faṣlü'l-maḳ̂al fî şerhi kitâbi'l-emșâl, 27.

114 Eren, Atasözleri ve Deyimler, 27.

115 el-Meydânî, Mecme'u'l-emsâal, 2/18.

116 el-‘Askerî, Cemheratü'l-ems ŝl, 2/92, 305; el-Meydânî, Mecme`u'l-emsâal, 1/208.

117 Köklügiller, Açıllamalı Atasözleri ve Özdeyişler, 94; Eren, Atasözleri ve Deyimler, 31.

118 el-‘Askerî, Cemheratü'l-emșâl, 1/493; el-Meydânî, Mecme`u'l-emșâl, 1/109, 265.
} 
Doğru olsa bile başkalarının işine gelmeyen sözleri, hatır gönül dinlemeyerek söyleyen kişiler sevilmez. ${ }^{119}$

\section{6. Çok Konuşmak ve Sükût Etmek}

Kişinin mutlu veya mutsuz olmasında dilini tutması oldukça önemlidir. Çünkü ağızdan çıkan kötü bir söz, kişinin başına bir yığın dert açabileceği ya da dostu düşman yapabileceği gibi, güzel ve tatlı bir söz de aleyhimize olacak şeyleri lehimize, düşmanlarımızı da dosta çevirebilir. Bu yüzden mesel ve atasözlerinde çok konuşmayıp sükût etmenin önemine vurgu yapılmıştır.

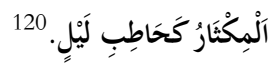

Çok konuşan, gece odun toplayan kimse gibidir.

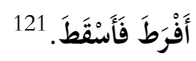

Çok konuştu, bu yüzden yanıldı.

\section{"Çok söyleyen çok yanillr"; "Çok bilen çok yannllr."}

Meselde çok konuşan kimse, gece odun toplayan kimseye benzetilmiştir. Çünkü karanlıkta odun toplayan kişi, eline her ne geçerse alabileceği gibi, çok konuşan kimse de olur olmaz bilmediği konularda konuşup yanılabilir. Bu manada söylenen

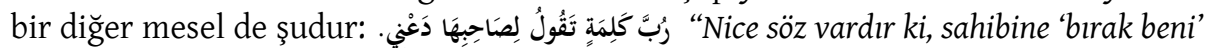
der." 122

$$
\text { آسُُكُوتُ أَخُو الِّرضًا. }
$$

Sükût, bir nevi razı olmaktır.

\section{"Sükût ikrardan gelir."}

Kişinin, kendisine sorulan sorulara suçlandığını bilerek karşılık vermemesi, bu suçu veya kabahati işlediği anlamına gelir. ${ }^{124}$

$$
\text { رُبَّ سُكُوتِ أَبْنَغْ مِنْ كَلَاِِ. } 125
$$

Nice susmak, konuşmaktan daha çok şey anlatır.

119 Eren, Atasözleri ve Deyimler, 72.

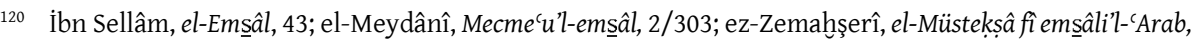
$1 / 349$.

121 el-'Askerî, Cemheratü'l-emsấl,1/19.

122 el-Meydânî, Mecme‘u'l-emsâal, 1/306.

123 el-‘Askerî, Cemheratül-emșâl, 1/521; el-Meydânî, Mecmécu'l-emșâl, 1/356; ez-Zemahșerî, el-Müstekșâ fî emsâli'l-'Arab, 1/325.

124 Atasözlerimiz, “Atasözleri ve Deyimler Sözlüğü” (Erişim: 12 Ekim 2020).

125 el-Meydânî, Mecme‘u'l-emsâal, 1/317. 


\section{“Söz gümüşse, sükût altındır."}

Konuşmak iyi olsa da, bazen susmak çok daha iyi netice verir. Konuşan kimse söylediği sözlere dikkat etmelidir. Bulunduğu her mekânda bir şeyler söylemek isteyen kimselerin hata yapması kaçınılmazdır. Bu yüzden bazen konuşmayıp dinlemeyi bilmek gerekir. ${ }^{126}$

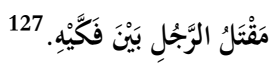

Kişinin ölümü iki çenesi arasındadır.

"Söz var iş bitirir, söz var baş yitirir."

Söylenen söz, insanlar üzerinde son derece etkilidir. Yerinde ve zamanında söylenen söz insanın lehine olurken, sert ve kaba bir şekilde söylenenler muhatabı kızdirabilir, hatta onun zarar vermesine bile neden olabilir.

$$
128 \text { سَوَاءُ قَوْلُلهُ وَبَوْلُهُ. }
$$

Sözü de bevli de aynı.

"Söylesen de boş, söylemesen de."

Kişinin söyleyeceği sözün bir öneminin olmadığını ifade eder.

\subsection{Sabırlı Olmak ve Tahammül Etmek}

Hayat zorluk ve sıkıntılarla doludur. İnsan zayıf bir varlık olduğu için bu sıkıntılara tahammül etmede ve direnmede zorlanır. Ancak bunlara sabretmekten başka çaresi de yoktur. Bu yüzden atasözlerinde başa gelenin çekileceği, sabrın sonunun güzel olacağı ve sabırlı olan kişinin sonunda emeline ulaşacağı vurgulanmaktadır.

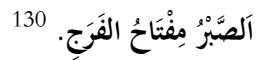

Sabır kurtuluşun anahtarıdır.

\section{"Sabur cennetin anahtaridır."}

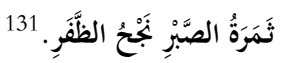

Sabrın meyvesi zaferin başarısıdır.

\footnotetext{
126 Atasözlerimiz “Atasözleri ve Deyimler Sözlüğü”.

127 el-‘Askerî, Cemheratü'l-emsâal, 1/493; el-Meydânî, Mecméu'l-emșâl, 2/265; ez-Zemahşererî, el-Müstekșâ fî emsâli'l-'Arab, 2/346.

128 el-Meydânî, Mecme‘u'l-emsâal, 1/356.

129 Vefik, Atalar Sözü, 199.

130 el-Meydânî, Mecme`u'l-emŝâl, 1/417.

131 el-Meydânî, Mecme‘u'l-emsâal, 1/154.
} 


\section{"Sabreyle işine hayır gelsin başına"; "Sabreden derviş muradına ermiş" "Sabrın sonu sela- mettir"; "Sabir actdir, meyvesi tatl."}

Sabırlı olan kimse, gerçekleşmesi zor görünen işlerde bile istediği başarıyı elde edebilir.

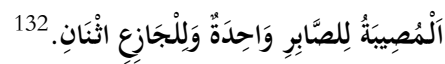

Sıkıntı (bela), sabreden için bir; sabırsız için iki tanedir.

\section{"Sabırla koruk helva olur, dut yaprağı atlas."}

İnsanın her istediği anında gerçekleşmez, belli bir süreye ihtiyaç duyar. Çünkü elverişli ortam ve koşullar henüz meydana gelmemiştir. ${ }^{133}$

$$
\text { حِيلَة مَنْ لَا حِيلَة لَهُ الصَّبْرُ. } 134
$$

Çaresi olmayan kimsenin çaresi, sabretmektir.

"Başa gelen çekilir."

Kişi, çaresiz kaldığı durumlarda ümitsizliğe düşmemeli, metanetli olmalıdır.

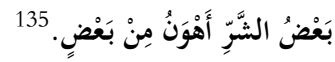

Bazı kötü şeyler diğerlerinden daha önemsizdir.

"Beterin beteri vardır"; "Gelen gideni aratır."

Yaşadığı kötü olaylara üzülen kimse, ondan daha kötülerinin de olduğunu düşünerek kendisini teselli etmelidir.

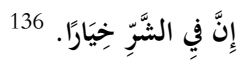

Şüphesiz şerde hayır(lar) vardır.

"Her işte bir hayır vardır."

Kişi, başına gelen her şeyi hayra yormalı, kötümserliğe kapılmamalıdır.

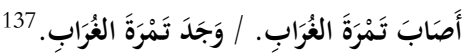

Karganın hurmasını buldu.

\footnotetext{
132 İbn Sellâm, el-Emŝâl, 161; el-`Askerî, Cemheratü'l-emsâll, 1/353.

133 Köklügiller, Açılamalı Atasözleri ve Özdeyişler, 192.

134 İbn Sellâm, el-Emşâl, 162; el-‘Askerî, Cemheratü'l-emşâl, 1/352; el-Meydânî, Mecmécu'l-emsâl, 2/265; ezZemahşerî, el-Müstekșấ fì emsâali'l-'Arab, 2/70.

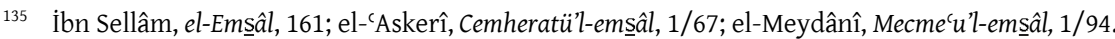

136 İbn Sellâm, el-Emŝâl, 161; el-‘Askerî, Cemheratü'l-ems ŝal, 1/67; el-Meydânî, Mecmécu'l-emsâal, 1/11.

137 el-'Askerî, Cemheratü'l-emŝâl, 2/333; el-Meydânî, Mecme`u'l-emŝâl, 1/404; 2/63; ez-Zemahşserî, el-Müstekșâ fi emsâli'l-'Arab, 2/373.
} 


\section{"Durdu durdu, turnayı gözünden vurdu."}

Karga hurmanın en iyisini bulup yediği için, uzun süre bekleyen ve çok arzuladığı şeyi elde eden kimseler için söylenilen bir meseldir.

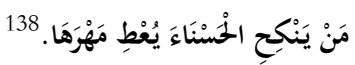

Kim güzel biriyle nikâhlanacaksa mihrini verir.

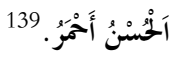

Güzellik kırmızıdır.

\section{"Gülü seven dikenine katlantr."}

Kişi, sevdiği kimseden veya yapmayı sevdiği bir işten kaynaklanan sıkıntılara katlanır. ${ }^{140}$

\section{8. Çalışmak ve Tembellik (Kararsızlık)}

Daha iyi yerlere gelmenin ve başarılı olmanın tek yolu çalışmaktır. Çalışarak her türlü sıkıntının, üzüntünün ve derdin üstesinden gelinebilir. İnsan yeter ki istesin ve gayret etsin. Allah Teâlâ çalışan kimselerin emeğini boşa çıkarmayacaktır. Ayrıca toplumda tembel kimseler sevilmezken; gayretli, çalışkan kişiler daha çok itibar ve takdir görür.

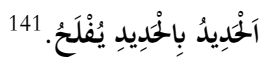

Demir demirle kesilir.

"Çivi çiviyi söker."

Güçlü ve sağlam olan, ancak kendisi gibi bir şeyle etkisiz hale getirilebilir. Bu yüzden zor işlerin üstesinden gelebilmek için sağlam bir iradeye sahip olmak gerekir. ${ }^{142}$

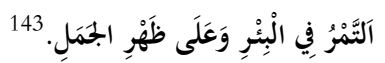

Hurma kuyunun içinde ve devenin sırtındadır.

\section{"Ekmek aslanin ağzında."}

\footnotetext{
138 el-‘Askerî, Cemheratü'l-emșâl, 2/258; el-Meydânî, Mecme‘u'l-emșâl, 2/300.

139 el-Meydânî, Mecme'u'l-emŝâl, 1/199; el-Yûsî, Zehru'l-ekem fi'l-emŝâl, 2/123.

140 Eren, Atasözleri ve Deyimler, 98.

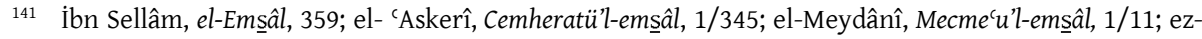
Zemahșerî, el-Müstekșâ fí emsâli'l-‘Arab, 1/403.

142 Eren, Atasözleri ve Deyimler, 58.

143 el-‘'Askerî, Cemheratü'l-emșâl, 1/264; el-Meydânî, Mecmécu'l-emșâl, 1/137; ez-Zemahşerî, el-Müstekșâ fî emsâali'l-‘Arab, 1/307.
} 
İhtiyaçları karşılamak ve geçim sağlamak için iyi gelir getiren bir iş bulmak kolay değildir.

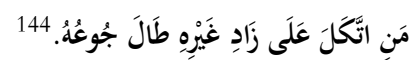

Kim başkasının azığına güvenirse, uzun süre aç kalır.

\section{"Uçan kuşaç kalmaz."}

Çalışan, yaşam kavgası veren kimse, ne yapar eder rızkını kazanır.

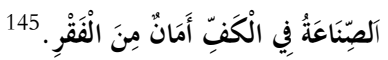

Eldeki zanaat fakirlikten kurtarır.

\section{"Sanat altin bileziktir"; "Varsa hünerin, var her yerde yerin."}

Altın bilezik hiçbir zaman değer kaybetmez ve gerektiğinde paraya çevrilebilir. Zanaat da buna benzer. Bir maharet ve hünere sahip kimse her zaman çalışacak bir iş bulur ve darda kalmaz. ${ }^{146}$

$$
\text { مَا حَكَُّ ظَهْرِي مِثْلُ يَدِي. } 147
$$

Sırtımı en iyi kendi elim kaşıdı.

\section{Kurda 'Neden boynun (ensen) kaln?' demişler, 'İşimi kendim görürüm de ondan' demiş.}

Sırtını başkasına dayamayıp, işini kendisi yapmaya çalışan kimse, rahata erer ve üzülmez.

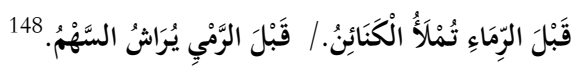

"Ok atılmadan önce tüyle kaplanır/Ok atmadan önce sadak doldurulur."

"Karıncadan ibret al, yazdan kış hazırla."

İnsanlar da karıncalar gibi olmalı. Gençliklerinde zamanlarını boşa geçirmemeli ve güçleri ölçüsünde çalışıp geleceğe hazırlanmalılar. ${ }^{149}$

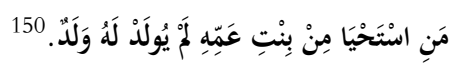

Amcasının kızından utanan kimsenin çocuğu olmaz.

\footnotetext{
144 el-Meydânî, Mecme`u'l-emșâl, 2/327.

145 el-Meydânî, Mecme $e^{`} u^{\prime}$-ems ŝal, 1/417.

146 Köklügiller, Açılamalı Atasözleri ve Özdeyişler, 193.

147 el-Meydânî, Mecme‘u'l-emșâl, 2/268; ez-Zemahşserî, el-Müstekșâ fî emșâli'l-‘Arab, 2/321.

148 el-‘Askerî, Cemheratü'l-emșâl, 2/122; el-Meydânî, Mecméu'l-emșâl, 2/101; ez-Zemahşserî, el-Müstekșâ fî emsâli'l-'Arab, 2/187.

149 Köklügiller, Açılamalı Atasözleri ve Özdeyişler, 183-184.

150 el-Meydânî, Mecme`u'l-emŝâl, 2/327.
} 


\section{"Üşenenin (utananın) oğlu kızı olmaz."}

Hayatını tembel tembel geçiren kimselerin ne bir işi ne de malı mülkü olur. Çaba sarf etmeden, yorulmadan, bazı zorlukları yaşamadan rahat bir ortama kavuşmak mümkün değildir. ${ }^{151}$

$$
\text { رُبَّ سَاعِع لِقَاعِدِ. }
$$

Çalışmayıp oturanlar yerine çalışan nice kimse vardır.

\section{"Kimse bilmez, kim kazana kim yiye."}

Bir kimsenin vakti zamanında büyük çaba sarf ederek kazandığı malı, bazen akla hayale gelmeyen kimseler yer.

$$
\text { آخِرُهَا أَقَلُلُهَا شُرْبًا. }
$$

Sona kalan en az içendir.

\section{"Sona kalan dona kalır."}

Bir işte geciken kimse, elde etmek istediği şeylere ulaşamaz ve hüsrana uğrar. ${ }^{153}$

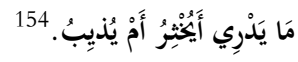

Tereyağını eritsin mi, eritmesin mi bilmiyor.

\section{"Aşağı tükürsem sakal, yukarı tükürsem bıyık."}

Birbirine zıt ve aynı oranda tehlikeli iki durum karşısında karar vermek zordur.

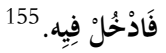

Bedava mezar bulursan içine gir.

"Bedava sirke baldan tatlıdır."

Çaba ve emek sarf etmeden bir şey elde etmek, insanların hoşuna gider.

\subsection{Tutumlu Olmak ve İsraf Etmemek}

Erdemli davranışlardan biri olan tutumluluk, sorumlu bireylerin yetişmesinde önemli rol oynar. Bu bireyler de ailesine, topluma ve ülkesine karşı kendisini sorumlu hisseder. Böylelikle sahip olduğu şeyleri ya da ülke kaynaklarını israf etmemeye özen gösterir.

151 Köklügiller, Açılamalı Atasözleri ve Özdeyişler, 197.

152 İbn Sellâm, el-Emșâl, 239; el-`Askerî, Cemheratü'l-emsẩl, 1/81, 305; el-Meydânî, Mecme‘u'l-emsấl, 1/41.

153 Eren, Atasözleri ve Deyimler, 184.

154 İbn Sellâm, el-Emŝâl, 298; el-Meydânî, Mecméu'l-emsâl, 2/281.

155 el-Meydânî, Mecmécu'l-emsâal, 1/87. 


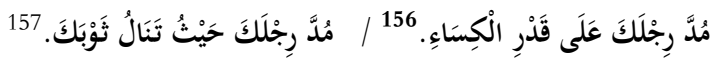

Ayağını örtüye göre uzat / Ayağını elbisene göre uzat.

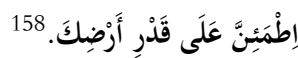

Bulunduğun yere göre (tarlanın miktarına göre) rahat ol.

\section{"Ayağını yorganına göre uzat."}

İnsan hayatında iyi kötü pek çok şeyle karşılaşabilir. İçinde bulunduğu iyi durum, mutluluk hep aynı şekilde devam etmeyebilir. Gelecek günlerin neler getireceği belli olmadığı için kişi, gelirine göre ve sahip olduğu olanakları aşmadan yaşamalıdır. ${ }^{159}$

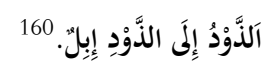

Bir deve başka bir deveyle bir araya gelince deve sürüsü olur.

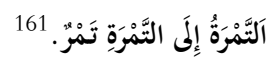

Bir hurma, başka hurmaya ilave edildiğinde çoğalır.

\section{"Damlaya damlaya göl olur"; "Her çok, azdan olur."}

Ufak tefek şeyleri önemsiz görüp az bulmak yanlıştır. Çünkü onlar bir araya gelince büyür ve çoğalırlar. Bu yüzden küçücük şeylerin bile değerini ve kıymetini iyi bilmek lazım. ${ }^{162}$

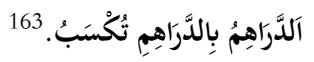

Para, parayla kazanılır.

\section{"Para, parayı çeker."}

Eldeki paralarla, yeni paralar kazanmak mümkündür. ${ }^{164}$

\footnotetext{
156 el-Meydânî, Mecmécu'l-emșâl, 1/435.

157 el-'Askerî, Cemheratü'l-emsấl, 1/117.

158 el-Meydânî, Mecme'u'l-emșâl, 1/435.

159 Köklügiller, Açıklamalı Atasözleri ve Özdeyişler, 104; Muallim Nâci, Sânihâatü'l-'Arab: Arap Edebiyatında Deyimler ve Atasözleri, haz. Ömer Hakan Özalp (İstanbul: Yeni Zamanlar Yayınları, 2002), 61.

160 İbn Sellâm, el-Emŝâl, 190; el-'Askerî, Cemheratü'l-emsâll, 1/462; el-Meydânî, Mecme'u'l-emsâal, 1/277; ezZemahșerî, el-Müstekșâ fí emsâali'l-'Arab, 1/322.

161 İbn Sellâm, el-Emșâl, 190; el-Meydânî, Mecme'u'l-emșâl, 1/137; ez-Zemahşerî, el-Müstekșâ fí emșâli'l'Arab, 1/307.

162 Eren, Atasözleri ve Deyimler, 63; Atasözlerimiz, “Atasözleri ve Deyimler Sözlüğü".

163 el-Meydânî, Mecme'u'l-emsâal, 1/274.

164 TDK, “Atasözleri ve Deyimler Sözlüğüu”; Eren, Atasözleri ve Deyimler, 171.
} 


\subsection{Kanaat Etmek ve Açgözlülük}

Kanaatkâr olmayıp hep daha fazlasını istemek kişiyi yorar ve küçük düşürür. Bu yüzden elimizdekilerle yetinip onlara razı olmayı bilmeli, açgözlü olmamalı ve başkalarının malına göz dikmemeliyiz

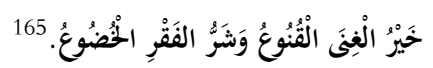

Zenginliğin en hayırlısı kanaat, fakirliğin en kötüsü boyun eğmedir.

"Kanaatte izzet, tamahta zillet vardir"; "Kanaat gibi devlet olmaz."

$$
\text { يَكْفِيكَ نَصِيبُكَ شُحَّ الْقَوْمْم. } 166
$$

Kavmin cimri olsa da nasibin sana yeter.

\section{“Azıcık aşım kaygısız başım."}

Hiçbir zaman aşırıya kaçmamak ve azla yetinmeyi bilmek gerek.

$$
\text { غَثُكَكَ خَيْرٌ مِنْ سبمِينِ غَرْرِكَ. } 167
$$

Senin zayıf olanın başkasının şişman olanından daha hayırlıdır.

"Evdeki ayran komşudaki yoğurttan iyidir"; “Çoğu zarar, azı karar.”

$$
\text { اَلْْحَشُشُ لَمَّا بَذَّكَ الْأَعْيَرُر. } 168
$$

Yaban eşek(ler)ine gücün yetmiyorsa sıpasıyla yetin.

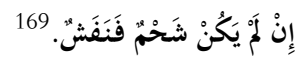

Yağ yoksa yün parçasına razı ol.

\section{“Aza kanaat etmeyen çoğu bulamaz"; "Bir başa bir göz yeter."}

Büyük şeylere sahip olabilmek için öncelikle küçük şeylerle yetinmeyi bilmek gerekir.

$$
\text { أُعْطِيَ الْعَبْدُ كُرَاعًا فَطَلَبَ ذِرَاعًا. } 170
$$

Köleye paça verildi, but istedi.

165 İbn Sellâm, el-Emșâl, 197-198; el-'Askerî, Cemheratü'l-emșâl, 2/236; el-Meydânî, Mecme'u'l-emsâal, 1/244; el-Yûsî, Zehru'l-ekem fi'l-emsâl, 2/206.

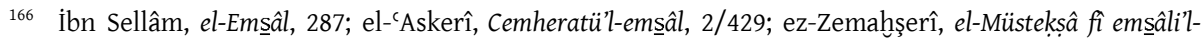
'Arab, 2/415.

167 el-'Askerî, Cemheratü'l-emșâl, 2/81; el-Meydânî, Mecme'u'l-emșâl, 2/58, 315; 2/63; ez-Zemahşerî, el-Müstekșâfi emsâli'il-'Arab, 2/176.

168 İbn Sellâm, el-Emșâl, 235; el-‘Askerî, Cemheratül'-emsâal, 1/297, 305; el-Meydânî, Mecme'u'l-emșâl, 1/165.

169 el-'Askerî,, Cemheratü'l-emsấl, 2/411; el-Meydânî, Mecme'u'l-emsâal, 1/47.

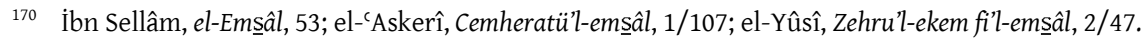




\section{"Yüz verince astarını ister"; "Bir buldu iki ister, akça buldu çıkın ister."}

Hiçbir zaman ellerinde olanla yetinmeyi bilmeyen hırslı insanlar, her zaman çok daha fazlasinı talep ederler.

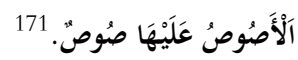

Asil deve üzerinde alçak kimse.

\section{"Kel başa şimşir tarak."}

Pek çok ihtiyacı olmasına rağmen, gereksiz gösteriş ve özentiyle uğraşanları ifade eder.

\subsection{Acele Etmemek ve Teenni ile Davranmak}

Yapacakları işlerde acele etmek, insanları maddi ve manevi zararlara uğratabilir. $\mathrm{Bu}$ yüzden herhangi bir hususta karar almadan veya bir davranışı yapmadan önce teenniyle davranmak gerekir. Aceleciliğin yerildiği ve teenni ile hareket etmenin methedildiği aşağıdaki meseller bu durumu bize en güzel şekilde ifade etmektedir:

$$
\text { ألْعَجَلَةُ فُرْصَةُ الْعَجَزَة. } 172
$$

Acele etmek acizler için fırsattır.

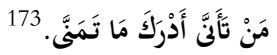

Teenniyle davranan umduğuna ulaşır.

\section{"Acele ile menzil alınmaz"; "Acele işin sonu pişmanlık."}

Düşünüp taşınmadan alelacele yapılan hiçbir işten verimli sonuç alınamaz. Bu yüzden hiçbir konuda acele etmemek gerekir. ${ }^{174}$

$$
\text { شَرُّ السَّيْرِ الحَقْحَقَةُ. } 175
$$

Yürüyüşün en kötüsü hızla yürümektir.

\section{“Acele yürüyen yolda kalı"; “Tez giden tez yorulur."}

Acele edip amacına en kısa yoldan ulaşmak isteyen kimse, istediğini elde edebilir belki ama çok yorulur.

\footnotetext{
171 el-Meydânî, Mecme'u'l-emŝâl, 1/24; ez-Zemahşerî, el-Müstekșâ fî emŝâli'l-‘Arab, 1/213.

172 el-Meydânî, Mecme'u'l-emsâal, 2/37.

173 el-Meydânî, Mecmécu'l-emsâal, 2/327.

174 Köklügiller, Açılamalı Atasözleri ve Özdeyişler, 79.

175 el-‘Askerî, Cemheratü'l-emsâal, 1/21, 544; el-Meydânî, Mecme‘u'l-emŝâl, 1/359; el-Yûsî, Zehru'l-ekem fi'lems $\underline{a} l, 3 / 228$.
} 


\subsection{Tatli Dilli Olmak ve Yermek}

Gönül okşayıcı tatlı sözler, insanlar arası pozitif enerjiyi ve iletişimi daha da artırır. Çünkü insanlar güzel sözler duymaktan ve kendini değerli hissetmekten hoşlanırlar. Kötü, yaralayıcı sözler ise hiçbir zaman unutulmaz. Bu yüzden tatlı dilli olmalı ve insanlara sevgi ile yaklaşmalıyız.

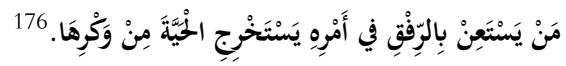

Kim yaptığı işte nazik olursa, yılanı deliğinden çıkarır.

\section{"Tatlı dil, yılanı deliğinden çıkarır."}

Yumuşak ve tatlı dilli olduğunuz sürece karşınızdaki kişiye her işi yaptırmak mümkündür.

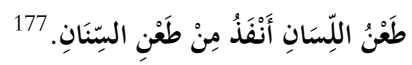

Dil yarası mızrak yarasından daha etkilidir.

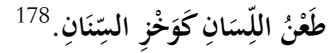

Dil yarası mırak yarası gibidir.

\section{"Bıçak yarası geçer (onulur), dil yarası geçmez (onulmaz)."}

Hakaret içerikli sözler ve kalp kırıcı davranışlar kesinlikle unutulmayıp yıllarca sürebilir. ${ }^{179}$

\subsection{Güzelliğin Göreceli Olması}

Güzellik ve beğeniler kişiden kişiye değișebilir. Akrabalık, yakınlık, arkadaşlık vb. diş faktörler de bir şeyi güzel görmede etkilidir. Bu yüzden kişi kendi yaptıkları işleri, çocuklarını veya yakınlarını genelde beğenir.

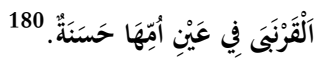

Böcek, annesine güzel görünür.

$$
\text { زَيْيَنَ في عَيْنِ وَالِِدِ وَلَدْد. } 181
$$

Babanın gözüne çocuğu güzel görünür.

\footnotetext{
176 el-Hâşimî, es-Siḥru'l-ḥalâl ve fi'l-ḥıkem ve'l-emșâl, 62.

177 ez-Zemahșerî, el-Müstekșâ fî emsâali'l-‘Arab, 2/151.

178 el-Meydânî, Mecme'u'l-emsâ̂l, 1/433.

179 Köklügiller, Açıklamalı Atasözleri ve Özdeyişler, 116.

180 el-Meydânî, Mecméu'l-emsâal, 2/97; ez-Zemahşerî, el-Müstekșâ fî ems ŝali'l-'Arab, 1/339.

181 el-c'Askerî, Cemheratü'l-emsâal, 1/350; el-Meydânî, Mecme'u'l-emŝâl, 1/319; ez-Zemahşerî, el-Müstekșâ fî emsâali'l-‘Arab, 2/112.
} 


\section{"Kuzguna yavrusu şahin (anka) görünür." \\ "Karga yavrusuna bakmış: "Benim ak pak evladım demiş"}

Başkalarına göre çirkin olsa bile, herkes kendi evladını güzel ve kusursuz olarak görür. Çünkü insanın kişisel beğenilerinde duygu ve zevkleri etkili olur. ${ }^{182}$

\subsection{Yanlış Anlama}

Sağır kimse, yanında konuşan kimselerin sözlerini işitmez ama onların davranışlarına ve mimiklerine bakarak söyledikleri şeyleri anladığını zannedip kendince yorumlar. Bunu şu mesel en güzel şekilde ifade eder:

$$
\text { أَسَاءَ سَمْمَا فَأَسَاءَ جَابَةُ. }
$$

Yanlış duydu, yanlış cevap verdi.

\section{"Sağır duymaz uydurur (yakıştırır)."}

Kendisine söylenen sözleri anlamadığı gibi, konuyla hiç ilgisi olmayacak şekilde sürekli yanlış yorumlar yapan kimseler için de şöyle bir mesel kullanılır:

$$
\text { لَوْ قُلْتُ تَمْرَةً لََقَالَ جَمْرَة. } 184
$$

Ben temra (hurma) desem, o cemra (köz) der.

\section{"Ben derim bayram haftası, o der mangal tahtası."}

\subsection{D1ş Görünüşe Aldanma}

D1ş görünüş yanıltıcı olabilir. Bu yüzden insanları değerlendirirken görünüşüne değil; bilgisine, konuşmasına, hal ve tavırlarına bakmak gerekir.

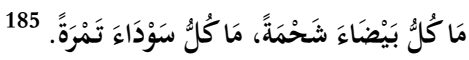

Her beyaz yă̆, her siyah hurma değildir.

\section{"Her sakallıyı deden sanma"; "Her gördüğ̈̈n sakallıyı baban sanma." \\ "Ak koyunu gören içi dolu yağ sanır."}

Herhangi bir şeyin dış görünüşüne bakıp, içinin de aynı olduğunu zannetmek yaniltıci olur.

\footnotetext{
182 Eren, Atasözleri ve Deyimler, 127; Vefik, Atalar Sözü, 77.

183 İbn Sellâm, el-Emșâl, 53; el-'Askerî, Cemheratü'l-emsâll, 1/25; el-Meydânî, Mecméu'l-emsâal, 1/330; ez-Zemahşşerî, el-Müstekșấ fi em sâali'l-'Arab, 1/153.

184 el-Meydânî, Mecme‘u'l-emsâal, 2/198.

185 el-‘Askerî, Cemheratü'l-ems ŝâl, 2/226, 287; el-Meydânî, Mecme'u'l-emșâl, 2/281.
} 


$$
\text { لَيْسَ الجُحَمَالْ بِالثِيَّابِ. }
$$

Güzellik elbiseyle değildir.

"Kalıp kıyafetle adam adam olmaz"; "Kilık kıyafetle adam adam olmaz" "Kürk ile börk ile adam olunmaz"; "Eşeğe altın semer vursalar, eşek yine eşektir."

Doğruluk, dürüstlük, bilgelik gibi insanı insan yapan değerler vardır. Bunlardan yoksun birisi her ne giyerse giysin hangi makamda olursa olsun değersizdir. Dış görünüşe, makam ve unvanlara çok fazla önem verip insanları buna göre değerlendirmek yerine, gösterdikleri davranışlara ve yaptıkları işlere bakıp bir kanaate varmak gerekir. ${ }^{187}$

\subsection{Mükemmel Olmama}

Herkesin hataları, kusurları olabilir. Çünkü hiç kimse mükemmel değildir. Önemli olan yaptı̆̆ımız hataları bilerek, isteyerek yapmamak ve onları düzeltmeye çalışmaktir.

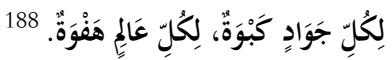

Her at tökezler, her bilen hata yapar.

"Hatasız kul olmaz" veya "Kul, hatasız olmaz."189

İnsan hata etmemek için her ne kadar uğraşsa da yine de yanılabilir.

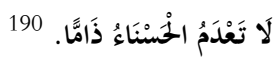

Güzeli de yeren bulunur.

\section{"Her güzelin bir kusuru vardır" veya "Kusursuz güzel olmaz." "Gül dikensiz olmaz" veya "Dikensiz gül olmaz."}

Her iyi ve güzel şeyin hoşa gitmeyen bir tarafi, kusuru vardır. Güzel şeye sahip olmak isteyen kimse bu kusurları görmezden gelmelidir. ${ }^{191}$

\subsection{Dert, Sikıntı ve Bela}

İnsanoğlu hayatta olduğu sürece pek çok sorun ve sıkıntıyla karşılaşıp üzülebilir. Ancak ölümle birlikte dertlerinden, tasalarından kurtulabilir. Bu yüzden başa gelen

\footnotetext{
186 el-Meydânî, Mecme'u'l-emșâl, 2/257.

187 Köklügiller, Açılamalı Atasözleri ve Özdeyişler, 33.

188 İbn Sellâm, el-Emsâal, 51; el-Meydânî, Mecme'u'l-emsâal, 2/187; el-Yûsî, Zehru'l-ekem fi'l-emsâal, 2/52.

189 Bu iki atasözünde olduğu gibi, manayı bozmamak şartıyla kelimeler arasında takdim-tehir yapılabilir. (bk. Dilçin, Edebiyatımızda Atasözleri, 23/.)

190 el-Meydânî, Mecme‘u'l-emșâl, 2/213; ez-Zemahşserî, el-Müstekșâ fî emșâli’-‘Arab, 2/256.

191 Eren, Atasözleri ve Deyimler, 70.
} 
acı ve kederlerden dolayı ümitsizliğe düşmemeli, üstesinden gelmeye gayret etmeli, gerektiğinde de başkalarından yardım istemeliyiz.

$$
\text { كُلُْ رَأسِ بِِ صُدَاعُ. } 192
$$

Her başın ağrısı vardır.

\section{"Ağrısız baş mezarda gerek."}

Yaşayan herkesin kendine göre sıkıntısı, derdi vardır. Ancak dünyadan göçüp gidildiğinde dertler bitecektir. Bu yüzden ufak tefek sıkıntıları dert edinip kötümser olmamakta fayda vardir.

$$
\text { فَرَّ مِنَ الْقَطرِ وَوَقَعَ تَحْنَ الْمِيزَابِ. } 193
$$

Damladan kaçtı, oluğun altına düştü.

\section{"Yağmurdan kaçarken doluya tutuldu."}

Güç bir durumdan kurtulayım derken daha kötüsüyle karşılaştı.

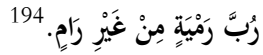

Atıcısı olmayan nice atış vardır.

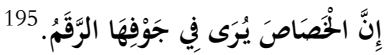

Küçük bir deliğin içinde büyük bir bela görülebilir.

\section{"Ummadiğın taş baş yarar."}

Beceriksiz sandığımız nice kişi, kendisinden umulmayan çoğu işi yapabilir. ${ }^{196}$

$$
\text { لالا بُدَّ لِلْمَصْدُورِ أَنْ يَنْفُثَ. }
$$

Göğsünden şikâyetçi olan kimsenin nefes alması gerekir.

"Derdini söylemeyen (saklayan) derman bulamaz."

İnsan ufak tefek sıkıntılarını kendi giderebileceği için başkasına söylemez. Fakat bazen çare bulmakta güçlük çektiği dertleri olabilir. Bu durumda etrafında kendisine yardımı dokunabilecek kimselerle konuşarak derdine çare bulabilir. ${ }^{198}$

\footnotetext{
192 el-Meydânî, Mecme'u'l-ems ŝal, 2/171.

193 el-Bekrî, Faṣlü'l-makâl fî şerhi kitâbi'l-emșâl, 378.

194 İbn Sellâm, el-Emsâal, 51, 312; el-‘Askerî, Cemheratü’l-emsâal, 1/491; el-Meydânî, Mecme‘u'l-emsâl, 1/299.

195 el-Meydânî, Mecmécu'l-emsâal, 1/12; ez-Zemahșerî, el-Müstekșâ fî emșâli'l-'Arab, 1/404.

196 Eren, Atasözleri ve Deyimler, 201.

197 el-Meydânî, Mecme`u'l-emŝâl, 2/241.

198 Köklügiller, Açıklamalı Atasözleri ve Özdeyişler, 144.
} 


\subsection{Bilme, Düşünme ve Tecrübeli Olma}

Bir konuda uzman, çok bilgili ya da tecrübe sahibi olan kimselere akıl öğretmeye ve bilgi vermeye çalışılmamalıdır. Zira bu hem gereksiz bir çabadır hem de küçük düşmemize sebep olabilir.

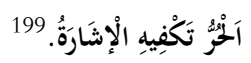

Hür kimseye işaret yeter.

\section{"Arife tarif gerekmez"; "Arif olan anlar."}

Herkesin anlayabileceği şekilde açıkça söylenmeyen bir sözün ne manaya geldiğini kavrayabilen kimselere açıklama yapmak gerekmez.

$$
200
$$

Tecrübeli orta yaşlı kimseye başörtüsünü nasıl örteceği öğretilmez.

\section{"Tereciye tere satilmaz."} tir. $^{201}$

Bir işte uzmanlaşmış kimselere o işi öğretmeye çalışmak, boşuna çaba sarf etmek-

$$
\text { كُلٌُ إنَاءٍ يَرْشَحُحُ بِمَا فِيهِ. } 202
$$

Her kap içindekini sızdırır.

\section{"Dervişin fikri neyse zikri odur."}

İnsan, konuşurken kafasındaki düşünceleri dile getirir. ${ }^{203}$

\subsection{Kader ve Kısmet}

Kader, meseller de dâhil olmak üzere birçok edebi eserde rol almıştır. Hem Arap hem Türk Edebiyatı'ndaki mesellerin ana teması şudur: Bir şey kaderde varsa mutlaka gerçekleşir; eğer yoksa siz ne kadar gayret ederseniz edin asla gerçekleşmez.

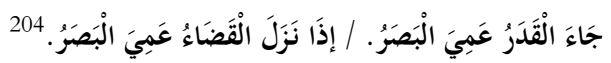

Kader gelince göz görmez olur.

$$
\text { إِذَا حَانَ القَضَاءُ ضَاقَ الْفَضَاءُ. }
$$

\footnotetext{
199 el-‘Askerî, Cemheratü'l-emsâal, 1/263; el-Meydânî, Mecme‘u'l-emŝâl, 2/19.

200 İbn Sellâm, el-Emsâal, 108; el-Meydânî, Mecme'u'l-emŝâl, 1/19.

201 Atasözlerimiz, “Atasözleri ve Deyimler Sözlüğü”.

202 el-Meydânî, Mecméu'l-emsâl, 2/162, 195.

203 Eren, Atasözleri ve Deyimler, 67.

204 ez-Zemahşerî, el-Müstekșâ fî emșâli'l-'Arab, 1/123; el-Yûsî, Zehru'l-ekem fi'l-em sâal, 1/75.

205 el-‘Askerî, Cemheratü'l-emsâal, 1/119; el-Meydânî, Mecme'u'l-emsâl, 1/60.
} 
Kader geldiğinde uzay (dünya) daralır.

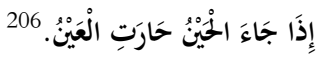

Ölüm gelince göz ne yapacağını şaşırır.

"Kısmetinde ne varsa kaşı̆̆ında o çıkar."

"Kısmet ise gelir Hint'ten Yemen'den, kısmet değilse ne gelir elden."

Kişi bir şeyi elde etmek için ne kadar çabalarsa çabalasın, Allah neyi kısmet ederse ona ulaşır. Kismet etmemişse onu elde edemezsiniz. ${ }^{207}$

$$
208 .
$$

Elden giden şey telafi edilmez.

\section{"Olmuşla ölmüşe çare yok (bulunmaz)."}

Olan bir şeyi değiştirmenin ve hayatı geri getirmenin mümkün olmadığını anlatan bir atasözüdür.

$$
\text { طَرَتْتُ بِهِ الْعَنْقَاءُ. } 209
$$

Anka kuşu onu alıp götürdü.

\section{"Yel üfürdü, su götürdü."}

Malın aniden ve sebepsiz bir şekilde yok olup gitmesini ifade eder.

\subsection{Evlilik ve Bekârlık}

Aynı konuda söylenilen bazı atasözlerine bakıldığında aralarında anlamsal bir çelişki olduğu görülmektedir. Mesela aşağıdaki evlilik ve bekârlıkla ilgili mesellerin birinde evlilik teşvik edilirken diğerinde bekârlık övülmektedir.

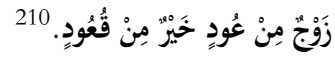

Çöp gibi zayıf biriyle evlenmek evde oturmaktan daha iyidir.

\section{"Koca olsun da isterse cüce olsun" "111 ; Bekârlık maskaralıktır."}

\section{"Bekârın parasını it yer, yakasını bit."}

\footnotetext{
206 el-Meydânî, Mecme'u'l-emșâl, 1/20.

207 Eren, Atasözleri ve Deyimler, 138.

208 el-'Askerî, Cemheratü'l-emsâal, 2/102.

209 el-'Askerî, Cemheratü'l-ems sâl, 2/13.

210 el-`Askerî, Cemheratü'l-emșâl, 1/503; el-Meydânî, Mecme`‘'l-emșâl, 1/320; ez-Zemahşserî, el-Müstekșâ fî emsâali'l-'Arab, 2/111.

211 Lutfi, Türk Atalar Sözü, 39.
} 
Bekâr kimsenin düzenli bir aile hayatı olmadığı, parasını çarçur ettiği ve derbeder bir yaşayışı olduğu için alay konusu olabilir.

Yukarıdaki atasözlerinde bekârlık yerilip evlilik teşvik edilirken, şu atasözünde de bekârlık övülmektedir.

$$
212 .
$$

Küçük büyük bunca felaketten sonra asla evlenmeyeceğim.

\section{"Bekârlık sultanlikttr."}

Evlenmeyip tek başına yaşamak daha iyidir.

\subsection{Birlik ve Beraberlik}

İnsan, tek başına zayıf bir varlıktır. Ancak başkalarıyla bir araya geldiğinde kendisini güçlü ve kuvvetli hissedebilir, herhangi bir işe girişebilir veya yaptığı işte daha başarılı olabilir.

$$
213
$$

Kurt yalnızken aslan kesilir. / Kurt yalnızken daha saldırgandır.

"Sürüden ayrilanı kurt kapar."

Bir amaç için topluca yapılan bir işten vazgeçenler hüsrana uğrarlar.

$$
\text { عَبْدُ صَرَيُْهُ أَمَةُ. } 214
$$

Kölenin yardımcısı cariye.

\section{"Bozactnın şahidi şıracı."}

Genelde aynı veya benzer düşüncelere sahip olanlar, birlik olur ve birbirlerine kol kanat gererler.

\subsection{Korkaklik}

Kişi hayatta başarılı olmak, zorluklara göğüs gerebilmek ve kendini tehlikelerden koruyabilmek için korkmamalı, cesaret sahibi olmalıdır. İște o zaman hayatından lezzet alabilir. Bu hususta şair bir beytinde şöyle der:

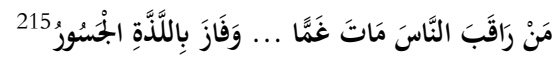

212 İbn Sellâm, el-Emŝâl, 256; el-Meydânî, Mecme'u'l-ems ŝal, 1/92.

213 İbn Sellâm, el-Ems ŝal, 222, 268; el- 'Askerî, Cemheratü'l-emsâal, 1/458, 459; el-Meydânî, Mecme'u'l-emsấl, 1/278; ez-Zemahşerî, el-Müstekșâfie emsâali'l-‘Arab, 1/319.

214 İbn Sellâm, el-Emşâl, 123; el-`Askerî, Cemheratü'l-emșâl, 2/40; el-Meydânî, Mecme‘u'l-ems̄âl, $2 / 5$.

215 el-Meydânî, Mecme'u'l-emŝâl, 2/402; el-Yûsî, Zehru'l-ekem fi'l-emŝâl, 3/135. 
Kim insanların sözüne kulak asarsa, kederden ölür.

Ancak cesaret sahibi kimse lezzeti tadar.

$$
216 \text { اَكْيْبَةُُ خَيْبَةُو. }
$$

Korkaklık kaybetmektir.

\section{"Bir korkak bir orduyu bozar."}

Toplum içinde bir iş yaparken ya da düşmanla savaşırken, korkak birinin sergileyeceği kaygı, korku ve telaş başarısızlığa yol açabilir.

$$
\text { إِنَّ الجُجَبَانَ حَتْفُهُ مِنْ فَوْقَهِ. } 217
$$

Korkağın ölümü üstünden (gökyüzünden) gelir.

"Korkunun ecele faydasi yoktur."

Kişi, korkarak başına gelecek bir kötülüğü engelleyemez. Bir şey olacaksa olur. Bu yüzden gereksiz korkuya kapılıp da üzülmemek gerekir. ${ }^{218}$

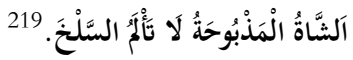

Boğazlanmış koyun, derisi yüzülürken acı duymaz.

“Ölmüş koyun (eşek) kurttan korkmaz"; "Islanmışın yağmurdan korkusu olmaz"; "Acı patlıcanı kırağı çalmaz."

Daha önce zarara uğrayan veya her şeyini kaybeden kimse, benzer kötü durumlardan etkilenmez. ${ }^{220}$

\subsection{3. İhtiyatlı Olmak}

Herhangi bir konuda bir şey söylerken veya yaparken, edinilen tecrübelerden yola çıkarak ileriyi düşünüp tedbirli davranmak gerekir. Aksi halde pişman olunacak durumlarla karşılaşılabilir veya aynı hataya düşülebilir.

$$
\text { إِنَّ لِلْحِيطَانِ آذَانَا. } 221
$$

Duvarların kulağı vardır.

\section{"Yerin kulağı vardır."}

\footnotetext{
216 el-Meydânî, Mecme'u'l-emsâ̂l, 2/402.

217 el-`Askerî, Cemheratü'l-emșâl, 1/114; el-Meydânî, Mecme`u'l-emșâl, 1/10; ez-Zemahşerî, el-Müstekșâ fî emsâli'l-'Arab, 1/403.

218 Eren, Atasözleri ve Deyimler, 143.

219 el-Meydânî, Mecmé 'u'l-emșâl, 1/391; ez-Zemahșerî, el-Müstekșâ fî emșâli'l-‘Arab, 1/325.

220 Eren, Atasözleri ve Deyimler, 168.

221 el-Meydânî, Mecme`u'l-emsâal, 1/87.
} 
İki kişinin gizlice konuştuğu bir mesele, başkaları tarafından duyulabilir. ${ }^{222}$

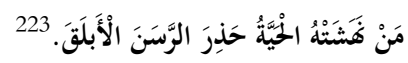

Kendisini yılan ısıran kimse, alacalı ipten sakınır.

\section{“Sütten ağzı yanan yoğurdu üfleyerek yer" veya "Sütten ağzı yanan ayranı üfleyerek içer."}

Yaptığı bir davranış veya işten dolayı zarar gören kimse, ikinci kez aynı hataya düşmemeye çalışır. ${ }^{224}$

\subsection{Borçlanma}

İnsan mecbur kaldığında bir yakınından veya arkadaşından daha sonra ödemek koşuluyla borç alabilir. Ancak zorunlu olmadıkça borç almamakta fayda vardır. Ayrıca elde hazır bulunan paraya da güvenmemeli, her daim çalışıp çaba gösterilmelidir.

$$
225 \text { اَبَجْمَلُ مِنْ جَوْفِفِه يَجْتَرُ. }
$$

Deve karnından geviş getirir.

\section{"Borçyiyen, kesesinden yer"; "Hazıra dağlar dayanmaz."}

Borç alarak alışveriş yapan kimse, aldığı şeylerin parasını o an kendisi vermese bile, daha sonra mutlaka ödeyecektir. Ayrıca kişinin çalışmayıp sürekli kesesinden harcaması da en büyük birikimleri bile eritir. ${ }^{226}$

\subsection{Firsatları Değerlendirmek}

Ele geçen firsatları kaçırmamak, iyi değerlendirmek gerekir. Kimi zaman fırsatı yakalamak kolaydır, yeter ki zamanı iyi ayarlanabilsin.

$$
227 .
$$

Rüzgârların estiğinde bunu firsat bil.

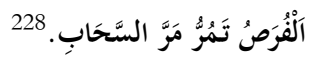

Fırsatlar bulut gibi geçer gider.

\footnotetext{
222 Eren, Atasözleri ve Deyimler, 214.

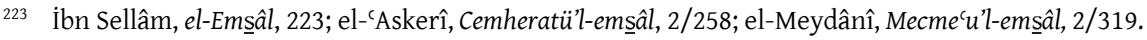

224 Köklügiller, Açılamalı Atasözleri ve Özdeyişler, 63.

225 el-Meydânî, Mecme ‘u'l-emșâl, 1/175; el-Yûsî, Zehru'l-ekem fi'l-emșâl, 2/51.

226 Köklügiller, Açıklamalı Atasözleri ve Özdeyişler, 167.

227 el-Hâşimî, es-Sihru'l-halâl ve fi'l-ḥıkem ve'l-emșâl, 105.

228 el-Meydânî, Mecméu'l-emsâ̂l, 2/90.
} 


\section{"Fursat her vakit ele geçmez."}

Fırsatlar insanın eline çok nadir geçer. Bu yüzden gelen her fırsat iyi değerlendirilmelidir.

\subsection{Zamanın Geçici Olması}

Her şeyin bir gerçekleşme süresi vardır. Sağlığımız ve durumumuz yerindeyken kendimizi işimize vermeli ve yapmamız gereken şeyleri gerçekleştirmeye özen göstermeliyiz. Çünkü zaman fark edemeyeceğimiz kadar hızlı geçmektedir.

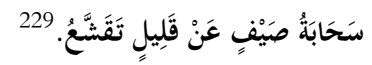

Yaz bulutu hemen dağılır.

\section{"Sayılı gün tez geçer"; "Gençlik bir kuştur, ihtiyarlık naçar iştir."}

Bir şeyin çabuk, hızlı bir şekilde geçtiğini ifade eden bu Arap meseline karşılık söylenen Türkçe ata sözlerde gençliğin ve sayılı günlerin çabuk geçtiği ifade edilmektedir.

\subsection{Açık Seçik Olmak}

Gerçekleri gizlemek, örtmeye çalışmak, görmezden gelmek boşa sarf edilen bir çabadır. Çünkü onlar ister istemez elbet bir gün açık seçik ortaya çıkacaktır.

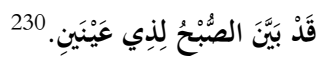

Gözleri olan için sabah aydınlandı.

\section{"Güneş balçıkla sıvanmaz."}

Herkes tarafından bilinen gerçekler inkâr edilemez.

\section{Hikâyesi Olan Meseller}

Mana yönünden Türk atasözleriyle uyumlu olan bazı Arap mesellerini anlayabilmek için sadece lafız yeterli olmamakta, hangi bağlamda söylenildiğini bilmek gerekmektedir. Bu yüzden aşağıdaki atasözlerinde mesellerin hikâyelerine de yer verilmiştir:

\section{وَافَقَ شَنٌْ طَبَقَةَ. 231}

229 el-Meydânî, Mecme'u'l-emsâ̂l, 1/344.

230 İbn Sellâm, el-Emŝâl, 59; el-`Askerî, Cemheratü'l-emsâal, 2/126; el-Meydânî, Mecme‘u'l-emsâal, 2/99; elBekrî, Fașlü'l-makâl fi şerhi kitâbi'l-emsâal, 61.

231 İbn Sellâm, el-Emŝâl, 177; el-‘Askerî, Cemheratü'l-emșâl, 2/336-337; el-Meydânî, Mecme`u'l-emŝâl, 2/359; ez-Zemahșerî, el-Müstekșâ fî emŝâli'l-‘Arab, 2/371. 


\section{Şenn, Ṭabaḳa'yla uyuştu. \\ “Tencere yuvarlanmış kapağını bulmuş."}

Bazı özellikler yönünden birbirine benzeyen iki kişinin bir araya geldiğini ifade eder. Meselin hikâyesi şöyledir:

Arapların dahi isimlerinden Şenn, kendisine uygun bir bayan bulup evlenene kadar gezip dolaşacağını söyler. Günlerden bir gün yolculuk yaparken, köyüne giden bir adamla karşılaşır ve köye kadar ona eşlik eder. Yolda giderken Şenn adama; "Sen mi beni taşırsın, ben mi seni?" diye sorar. Adam da "Ey kendini bilmez! İkimiz de bineğin üzerindeyiz. Birbirimizi nasıl taşıyalım" der. Sonra yolculuğa devam ederler. Biraz yol aldıktan sonra, hasat edilecek bir ekin tarlası görürler. Şenn adama "Bu ekin yenilmiş midir, yenilmemiş midir?" diye sorar. O da "Seni cahil! Ekinlerin yenilmediğini görmüyorsun" diye cevap verir. Sonra yollarına devam ederler. Yolda giderken bir cenazeyle karşılaşırlar. Şenn adama; "Sence tabutun içindeki kişi ölü müdür, diri midir?” diye sorar. Adam da "Senden daha cahilini görmedim. Sence onu mezara canlı mı götürüyorlar?" der.

Köye vardıklarında adam evine gider ve kızı Ṭabaḳa'ya yolda Şenn ile aralarında geçen konuşmaları anlatır. Tabaka da Şenn'in sorduğu soruların ne anlama geldiğini babasına şöyle izah eder:

"Sen mi beni taşırsın, ben mi seni?" sorusuyla "Yolculuk bitene kadar sen mi konuşmak istersin, ben mi konuşayım?” demek istemiştir.

"Bu ekin yenilmiş midir, yenilmemiş midir?" diyerek de "Ekinin sahibi ekinleri satıp parasını yemiş midir, yememiş midir” diye sormuştur.

“Sence tabutun içindeki kişi ölü müdür, diri midir?” diye sorarak da "Arkasında soyunu devam ettirecek evlat bırakmış mıdır?" öğrenmek istemiştir.

Günlerden bir gün adam Şenn'le karşılaşır ve ona kızının söylediklerini anlatır. Verdiği cevaplardan Ṭabaḳa'nın zeki bir kız olduğunu anlayan Şenn, onu babasından ister ve evlenirler. Daha sonra birlikte Şenn'in ailesinin yanına giderler. Tabaḳa'nın da Şenn gibi ak1llı ve zeki olduğunu anlayan aile وَافَقَ شَنٌْ طَبَقَة der.

$$
233 .
$$

Ellerin bağladı, ağzın şişirdi.

\section{"Kendin ettin kendin buldun"; "Kendi düşen ağlamaz."}

Mesel, kendisini kötü duruma düşüren kimselerin bundan dolayı yakınmamaları gerektiğini ifade eder. Meselin ortaya çıkış hikâyesi şöyledir:

\footnotetext{
232 el-‘Askerî, Cemheratü'l-emșâl, 2/336-337; el-Meydânî, Mecme'u'l-emșâl, 2/359.

233 İbn Sellâm, el-Emșâl, 331; ez-Zemahşserî, el-Müstekșâ fí emṣâli'l-‘Arab, 2/410.
} 
Adamın biri denizdeki adalardan birinde mahsur kalır. Bunun üzerine su kırbasını şişirip onunla karşıya geçmek ister. Kırbayı şişirir ama ağzını sıkıca bağlayamaz. Bu yüzden denizin ortasında kırbanın havası iner ve boğulma tehlikesi geçirir. Yardım istemek için bağırmaya başlayınca da adamın biri ona, "Ellerin bağladı, ağzın da şişirdi" der. ${ }^{234}$

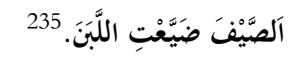

Sütü yazın kaybettin.

\section{“Geçti Bor'un pazarı, sür eşeği Niğde'ye."}

\section{"Atı alan Üsküdar'ı geçti"; "Eski çamlar bardak oldu."}

İşişten geçti anlamına gelen bu meselin hikâyesi şöyledir:

Kabilesinin en zenginlerinden biri olan 'Amr b. 'Amr b. 'Udâs, yaşlı olduğu halde kendisinden çok daha genç olan amcasının kızıyla evlenir. Ancak kız, 'Amr'dan hoşlanmaz ve boşanırlar. Daha sonra yakışıklı bir gençle evlenir. Onunla da geçim sıkıntısı çeken kız, bir gün süt istemek üzere eski kocasına gider. Eski kocası da ona şöyle cevap verir: 236

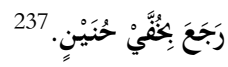

Ḥuneyn'in ayakkabılarıyla döndü.

\section{"Dimyat'a pirince giderken evdeki bulgurdan oldu." "Deve boynuz ararken kulaktan olmuş."}

Elindekini yeterli bulmayıp daha çoğunu ve iyisini isteyen kimse, sahip olduğu şeyleri de kaybeder anlamına gelen bu meselin ortaya çıkma hikâyesi şöyledir:

Bedevinin biri Ḥuneyn isimli bir ayakkabıcıya gidip, ondan bir çift ayakkabı almak ister. S1kı bir pazarlıktan sonra anlaşamayınca ayakkabıları almaktan vazgeçer. Bu duruma sinirlenen Ḥuneyn de bedeviyi kızdırmak için onun almak istediği ayakkabının önce bir tekini, daha sonra da diğer tekini onun geçeceği yolun üzerinde farklı yerlere koyar, kendisi de ağacın arkasına saklanır. Bedevi yolda giderken ayakkabının bir tekini gördüğünde “Huneyn'in ayakkabısına ne kadar da benziyor! Diğer teki

234 İbn Sellâm, el-Ems ŝal, 331.

235 İbn Sellâm, el-Emsâal, 247-248; el-‘Askerî, Cemheratü'l-emșâl, 1/575-576; el-Meydânî, Mecme`u'l-emsâll, 2/68; ez-Zemahşerî, el-Müstekșâ fìemŝâli'l-'Arab,1/329. (Bu manada kullanılan bir diğer mesel de şudur:

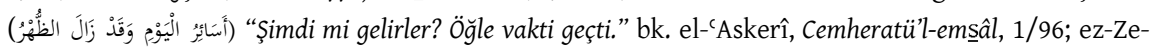
mahşserî, el-Müstekșấ fi em șâli'l-`Arab, 1/153; el-Yûsî, Zehru'l-ekem fi'l-emșâl, 3/155.)

236 el-'Askerî, Cemheratü'l-emsấl, 1/576; el-Meydânî, Mecme‘u'l-emșâl, 2/68.

237 el-Meydânî, Mecmécu'l-emsâal, 1/296; el-Yûsî, Zehru'l-ekem fi'l-emsâ̂l, 3/50. Bu manada kullanılan bir di-

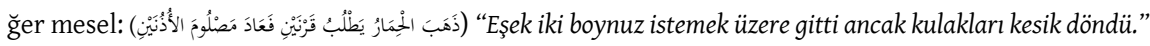
bk. el-Meydânî, Mecme‘u'l-emsâal, 1/286. 
de olsa onu alırdım" der. Daha sonra yoluna devam eden bedevi, biraz ilerde de ayakkabının diğer tekini görünce, ilk gördüğü ayakkabıyı almadığına pişman olur. Devesini yakınlarda bir yere bağlayıp önceki gördüğü ayakkabıyı almaya gider. Bunun üzerine Huneyn saklandığı yerden çıkıp bedevinin devesini eşyalarıyla birlikte alıp gider. Ailesinin yanına devesi ve eşyaları olmadan eli boş dönen bedeviye "Yolculuktan ne getirdin?" diye sorulduğunda "Huneyn'in ayakkabılarını" cevabını verir. ${ }^{238}$

$$
239 .
$$

Sinimmar’ı cezalandırdığı gibi cezalandırdı.

\section{"Besle kargayı oysun gözünü."}

Kendisine yapılan iyiliğin kıymetini bilmeyen ve iyiliğe karşılık kötülük yapan kimseler için söylenen bu meselin hikâyesi şöyledir:

Meselde adı geçen Sinimmâr Rum asıllı bir yapı ustasıdır. Kûfe'de Nu'mân b. İmrii'l-Kays için eşsiz bir saray inşa eder. Sarayı çok beğenen Nu'mân, aynısından bir başkası için de yapmaması için Sinimmâr'ı sarayın tepesinden aşağıya attırır ve Sinimmâr oracıkta can verir.

$$
240 .
$$

Kasîir, bir nedenden dolayı burnunu kesti.

\section{"Minareyi çalan kılffinı hazırlar."}

Gizlenmesi oldukça zor ve büyük bir suç işleyen kişi, karşılaşacağı cezalardan kurtulmasını sağlayacak yolları önceden düşünür. ${ }^{241}$ Öç almak istenildiğinde söyleni$\operatorname{len}^{242}$ bu meselin hikâyesi şöyledir:

Cezîmetü'l-Ebraş adında biri, Cezîre kraliçesi ez-Zebbâ'nın babasını öldürür. Bu duruma öfkelenen ez-Zebbâ, Cezîme'den intikam almak için ona bir mektup yazar ve ülkeyi birlikte yönetmeyi teklif ederek en kısa zamanda saraya gelmesini ister. Adamlarıyla istişare eden Cezîme bu teklifi kabul eder. Ancak adamlarından biri olan Kasîr, bunun iyi bir fikir olmadığını, bu işte bir intikam niyetinin bulunabileceğini, ez-Zebbâ'nın onun sarayına gelmesini istemesini söyler ama Cezîme onun sözüne itibar etmez. Saraya gittiğinde de ez-Zebbâ onu öldürür.

Bunun üzerine Kașîr Zebbâ'yı öldürme planları yapar. Burnunu kesip vücuduna da zarar vererek Zebbâ'nın yanına gider ve ona Cezîme’nin kız kardeşinin oğlu 'Amr

\footnotetext{
238 el-Meydânî, Mecme`u'l-emșâl, 1/296; el-Yûsî, Zehru'l-ekem fi'l-emșâl, 3/50.

239 İbn Sellâm, el-Emsâal, 273; el-‘Askerî, Cemheratü'l-emsâ̂l, 1/305; el-Meydânî, Mecme‘u'l-emsấl, 1/159.

240 el-Meydânî, Mecme'u'l-ems ŝal, 2/196; el-Yûsî, Zehru'l-ekem fi'l-emsâ̂l, 1/208.

241 Eren, Atasözleri ve Deyimler, 158.

${ }^{442}$ Ebû Manșûr es-Se'âlebî‘'Abdülmelik b. Muhammed, et-Temsîll ve’l-muhâdara, thk. 'Abdulfettâh Muhammed (y.y.: ed-Dâru'l-‘Arabiyye, 1981), 312.
} 
b. 'Adînnin ona bu işkenceyi yaptığını ve kendisine sığınmak istediğini söyler. Zebbâ da onun sarayda kalmasına izin verir. Sarayda kaldığı süre zarfında her türlü bilgiyi toplayıp Zebbâ'nın güvenini kazanan Kasîr, bir gün Zebbâ'dan izin alarak saraydan ayrılır. 'Amr'ın yanına gidip olup biten her şeyi ona anlatır. Daha sonra 'Amr ve adamlarını Zebbâ'nın yaşadığı şehre getirir ve gizlice saraya sokar. 'Amr'ı gören Zebbâ işin gerçeğini anlar ama 'Amr onu oracıkta öldürür. Bu olaydan dolay1 لِعَمْ denilir. ${ }^{243}$

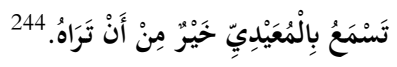

Mu'aydî’yi dinlemen, görmenden daha hayırlıdır.

\section{"Davulun sesi uzaktan hos gelir."}

Bazı durumlar vardır ki, uzaktan baktığınızda imrenirsiniz. Oysa gerçek hiç de göründüğü gibi değildir. İmrendiğiniz o şey, aslında sizi rahatsız edebilir. ${ }^{245} \mathrm{Bu}$ durumu anlatan meselin hikâyesi şöyledir:

Mu'aydî, adam öldüren ve en-Nu'mân b. el-Münżir'in mallarını gasp eden biridir. $\mathrm{Bu}$ yüzden adamları onu yakalamaya çalışır ancak bir türlü muvaffak olamazlar. Nu'mân, aynı zamanda kahramanlık ve cesaretinden dolayı Mu'aydî'yi beğenmekte ve onu görmek istemektedir. Günlerden bir gün $\mathrm{Mu}$ 'aydî Nu'mân'ın huzuruna gelir.

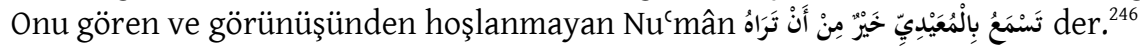

\section{Sonuç}

Uzun uzadıya anlatılacak bir olayı kısa ve öz bir șekilde ifade eden atasözleri, insanların üzerinde etkiler bırakarak hayatlarına yön vermektedir. Milletler farklı olsa bile insanoğlunun benzer deneyim ve yargılara sahip olması, lafız ve mana birliği içeren sözlerin ortaya çıkmasında etkili olmuştur. Arapça ve Türkçede ortak çağrışımlara sahip olan atasözlerine bakıldığında adalet, eşitlik, doğruluk, dürüstlük, yalan söylememe, cömertlik, dostluk, arkadaşlık, düşmanlık, tembellik, çalışmak, kanaat etmek, sabırlı olma, yardımlaşma, ölüm, kader, aşk, sevgi, para vb. pek çok konuda insan ve topluma dair söylenen sözler dikkati çekmektedir. Bu sözlerde zaman zaman, insanlarla olan ilişkilerinden yola çıkarak bitki, hayvan ve cansız varlıklara da yer verildiği görülmektedir.

Bahsi geçen atasözlerine cümle yapısı açısından bakıldığında isim, fiil ve şart cümlelerini görmek mümkündür. Bunların bazılarında olumlu-olumsuz ve talep ya-

\footnotetext{
243 el-Meydânî, Mecme'u'l-emsâal, 1/233; el-Yûsî, Zehru'l-ekem fi'l-emșâl, 1/210.

244 İbn Sellâm, el-Emșâl, 97; el-Meydânî, Mecmécu'l-emșâl, 1/129; ez-Zemahșerî, el-Müstekșâfí emșâli'l-'Arab, $1 / 345,346$.

245 Köklügiller, Açklamalı Atasözleri ve Özdeyişler, 140.

246 el-Yûsî, Zehru'l-ekem fi'l-emsâll, 3/176-177.
} 
pısı içeren bazılarında da maḩzûf öğelerin bulunduğu cümleler yer almaktadır. Ayrıca takdim te'hîr yapılan veya bir kelime yerine aynı manaya gelen başka bir kelimenin kullanıldığı meseller de bulunmaktadır. Anlatım biçimleri yönünden de dolaylı, dolaysız, karşılaştırmalı, soru cevaplı anlatımlara rastlanmaktadır. Doğrudan anlatıma sahip olanlarda verilmek istenen temel düşünce hemen anlaşılırken, dolaylı anlatıma sahip olanların ya da sadece lafza bakılarak anlaşılması mümkün olmayan mesellerin hangi bağlamda söylenildiğini araştırıp bilmek gerekmektedir. Makalede bahsi geçen meseller (atasözleri) edebi ve belagat yönünden değerlendirildiğinde de teşbih, istiare, kinaye, seci, cinas gibi beyan ve lafzi sanat türlerine rastlamak mümkündür.

Çıkar Çatışması / Conflict of Interest: Yazar çıkar çatışması olmadığını beyan etmiştir. / The author declared that there is no conflict of interest.

Finansal Destek / Grant Support: Yazar bu çalışma için finansal destek almadığını beyan etmiştir. / The author declared that this study has received no financial support. 


\section{Kaynakça}

'Âbidîn, 'Abdülmecîd. el-Emsâl fi'n-nesri'l-‘arabiyyi'l-kadîm. İskenderiye: Dâru'l-Ma'rife el-Câmiciyye, ts.

'Askerî. Ebû Hilâl. Cemheratü'l-emsâl. 2 Cilt. thk. Muhammed Ebu'l-Faḍl İbrâhîm- 'Abdülmecîd Kutâmış. y.y.: Dâru’l-Fikr, 1988.

Atasözlerimiz, “Atasözleri ve Deyimler Sözlüğü” Erişim: 12 Kasım 2020. www.atasözlerimiz.com.tr

Bekrî, Ebû 'Ubeyd. Faṣlü'l-makâll fi șerhi kitâbi'l-emsâl. thk. İhsân 'Abbâs. Beyrût: Müessetü'r-Risâle, 1971.

Demirayak, Kenan. Arap İslam Edebiyatı Literatür Bilgisi. İstanbul: Cantaş Yayınları, 2016.

Dilçin, Dehri. Edebiyatımızda Atasözleri. Ankara: Türk Dil Kurumu Yayınları, 2000.

Durmuş, İsmail. “Mesel”. Türkiye Diyanet Vakfi İslâm Ansiklopedisi. 29/299-301. Ankara: Diyanet Vakfı Yayınları, 2004.

Elmalı, Hüseyin. "Mufaḍḍal ed-Ḍabbî”. Türkiye Diyanet Vakfi İslâm Ansiklopedisi. 30/364. Ankara: Diyanet Vakfı Yayınları, 2004.

Eren, Şükran. Atasözleri ve Deyimler. İstanbul: Meram Yayınları, 1996.

Hâşimî, Ahmed. es-Sihru'l-halâl ve fi'l-ḥıkem ve'l-emsâl. Beyrût: Dâru'l-Kütübi'l-cillmiyye, ts..

Ișbahânî, Ebu'ş-Şeyh. Kitâbü'l-emsâl fi'l-hadîsi'n-nebevî. thk. 'Abdü'l-'Alî 'Abdülhamâîd Hâmid. Bombây: ed-Dâru's-Selefiyye, 1987.

İbn 'Abdi Rabbih. el-'Ikdü’l-ferîd. 8 Cilt. Beyrût: Dârü'l-Kütübi'l-'İlmiyye, 1404.

İbn Ḥamdûn, Muḥammed b. el-Ḥasen b. Muhammed b. 'Ali. et-Tezkiretü'l-ḥamdûniyye. 2 Cilt. Beyrût: Dâru Șâdır, 1417.

İbn Manẓûr, Muhammed b. Mükerrem. Lisânü'l-'Arab. 15 Cilt. Beyrût: Dâr-u Ṣâdır, ts..

İbn Sellâm, Ebû 'Ubeyd el-Ḳâsım. el-Emsâl. thk. 'Abdülmecîd Kutâmış. y.y.: Dâru'lMe’mûn, 1980.

Köklügiller, Ahmet. Açıklamalı Atasözleri ve Özdeyişler. İstanbul: Kaya Yayınları, 1994.

Kutâmış, 'Abdülmecîd. el-Emsâlü'l-'Arabiyye. Sûriye: Dâru'l-Fikr, 1988.

Lutfi, Muẓaffer. Türk Atalar Sözü. y.y.: Matbaai Ebüzziya, 1928.

Meydânî, Ebu'l-Faḍl Ahmed b. Muhammed. Mecméu'l-emsâl. 2 Cilt. thk. Muhammed Muhyiddîn 'Abdülhamîid. Beyrût: Dâru'l-Ma'rife, ts. 
Muṣtafa, İbrâhîm vd. el-Mu'cemu'l-vesitt. 2 Cilt. thk. Mecme`u'l-Lugati'l-'Arabiyye. y.y.: Dâru'd-Da've, t.y.

Nâci, Muallim. Sânihâtü'l-'Arab: Arap Edebiyatında Deyimler ve Atasözleri. haz. Ömer Hakan Özalp. İstanbul: Yeni Zamanlar Yayınları, 2002.

Secâlebî, Ebû Manșûr. et-Temsîl ve'l-muhậdara. thk. 'Abdulfettâh Muhammed. y.y.: edDâru'l-'Arabiyye, 1981.

Tüccar, Zülfikar. "Meydânî, Aḥmed b. Muhammed”. Türkiye Diyanet Vakfi İslâm Ansiklopedisi. 29/501-502. Ankara: Diyanet Vakf1 Yayınları, 2004.

TDK. “Atasözleri ve Deyimler Sözlüğü”. Erişim 11 Kasım 2020. https://sozluk.gov.tr.

Vefik Paşa, Ahmet. Atalar Sözü (Münteḩabât-ı Durûb-ı Emsâl). haz. Recep Duymaz. İstanbul: Gökkubbe Yayınları, 2007.

Yazıcı, Numan. Atasözleri ve Deyimler. İstanbul: Rağbet Yayınları, 2003.

Yûsî, Ebû 'Ali el-Hasen b. Mes' 'ûd b. Muhammed Nûruddîn. Zehru'l-ekem fi'l-ems âl ve’lhııem. 3 Cilt. thk. Muhammed Hacı, Muhammed el-Ahḍar. el-Magrib: Dâru'sSekâfe, 1981.

Zemahşerî, Ebu'l-Ḳâsım Mạ̣mûd b. 'Umer. el-Müșteksâ fî emsâli'l-'Arab. 2 Cilt. Beyrût: Dâru'l-Kütübi'l-cilmiyye, 1987. 


\section{Common Connotations in Arabic and Turkish Proverbs}

\section{Extended Summary}

The masal مثل (proverb), which is derived from the word "musûl" مثول meaning "to be like" in Arabic and comes in the form of plural أمثال, is one of the prose genres in Arabic Literature and has a literary value. These words, which emerge as a result of bittersweet events, happiness, disasters, experiences gained from historical events, constitute the unique feelings, tastes and literature of each nation; They are like mirrors reflecting the culture and civilization level, lifestyle, social and spiritual structure of the society they live in. In addition, they can easily stay in memory due to the accuracy of the information and ideas they contain and their short and concise sentences, and they contribute to the learning of the native language thanks to its rich meaning.

In Arabic Literature, proverbs are divided into three as mûcez, comparative and superstition. Mûcez proverbs are short and commonly used. Comparative ones; They are proverbs that contain descriptions and stories that aim to explain or provide evidence to an idea through tashbih or tamsil. It is possible to see such proverbs mostly in the Quran and hadiths. Later, analogies in the style of the Quran and hadiths were formed by Islamic scholars. Proverbs containing the superstition constitute the words transferred from the language of animals. These have no real or rational side. The aim is consolation, entertainment, and promotion of moral qualities. In the style of these proverbs, literary arts such as tashbih, istiara (metaphor), kinâya (metonymy), cinas (pun) and tıbâk (antithesis) attract attention. Being stereotypes is one of their philological features.

The proverbs can be divided into two as those belonging to the period of Jahiliyyah and those belonging to the Islamic period. The proverbs of Jahiliyyah can be distinguished by being attributed to the people living in that period, the customs and beliefs of Jahiliyyah, or war, news and events. The fact that proverbs are attributed to verses, hadiths, and the words of al-sahabah or al-tâbiûn show that they belong to the Islamic period.

Many proverbs in Arabic Literature, which are usually passed down orally from generation to generation, were first mentioned in the Umayyad period since the period of Mu'âviye b. Abû Sufyân, it has been tried to be brought together in books named "Emsâl". The oldest proverb book from these works to date is "Kitâbu'lemsâl" written by al-Mufaḍdal ed-Ḍabbî. The work, which is not too voluminous and deals with about 160 proverbs together with their emergence stories, constitutes the main source of later studies. "Kitâbu'l-emsâl" of al-Asma'î, one of the prominent figures of the Basra language school, is also one of the first works written in this field and deals with more than 500 proverbs. There are also more voluminous works 
copyrighted in this area. One of them is Abû Hilâl al-'Askerî's "Cemheretü'l-emsâl", which includes approximately 3000 proverbs, and the other is Meydânî's "Mecma'u'l-emsâl", which deals with approximately 6000 proverbs. Zemahşeri's "alMüstekșâ fî emsâli'l-'Arab" which is perhaps the last of the proverb books that has survived until today, is one of the comprehensive works that contain 3461 proverbs. When looking at these works containing proverbs, it is possible to obtain information about the personal characteristics, socio-cultural structure and history of the Arab people, as well as the lexical and grammatical structure of the Arabic language.

Cultural exchange between the nations was also reflected on the proverbs, and Turks met with Arabic proverbs both with religious, social and commercial relations and with the translation of Arabic sources into Turkish. One of the best examples of this is the book of named "Mahmûdu'l-eser fî tercemeti'l-mustațrafi'l-musta'sar" which was translated into Ottoman Turkish by Şeyhzâde Muhammed Es'ad Efendi. This is the Ottoman translation of Ibşîhî's book "el-Mustațraf fî kulli fennin mustazraf". Another work is "al-Okyânûsu'l-basît fî tercemeti'l-kâmusi'l-muhîț", which was enriched with Arabic proverbs while being translated into Turkish by the translator Asım Efendi. This book is a translation of the famous Arabic dictionary "el-Kâmûsü'lmuhît"of al-Fîrûzâbâdî into Ottoman Turkish.

It draws attention that there are similarities between proverbs in Arabic Literature, which have a deep-rooted and rich historical background and which are seen to affect Turkish Literature, and Turkish proverbs. This similarity is sometimes in terms of both word and meaning, and sometimes only in terms of meaning. The proverbs that are compatible in terms of meaning are words that can be understood sometimes from word, sometimes only when the story of their emergence is learned. For this reason, some proverbs in the research have been handled and evaluated together with their stories. The article includes proverbs that are found in classical precedent books and have the same or common words and meanings with proverbs in Turkish, and they are categorized under three main headings:

\section{Common Proverbs in Terms of Word and Meaning}

In the proverbs, which are common in terms of both word and meaning in Arabic and Turkish, it is seen that the words sometimes completely overlap with each other, and sometimes there are small changes due to a single word difference or lack.

2. Common Proverbs that are only in terms of meaning

Arabic proverbs, which are similar to Turkish proverbs not only in terms of wording but only in terms of meaning; It is concerned with many issues such as truthfulness, honesty, goodness, evil, friendship, kinship, neighborhood, unity, beauty, haste, patience, taking advantage of opportunities, being thrifty, fate, and fortune.

3. Proverbs with a story 
In order to understand some Arabic proverbs that are in harmony with Turkish proverbs in terms of meaning, words alone are not enough, it is necessary to know the context in which they are said. For this reason, the emergence stories of some proverbs are also included in the article.

Keywords: Arabic Literature, Turkish Literature, Prose, Proverb, Likeness. 